\title{
Brain region-specific susceptibility of Lewy body pathology in synucleinopathies is governed by a-synuclein conformations
}

\author{
Laura de Boni $^{1,2} \cdot$ Aurelia Hays Watson $^{1} \cdot$ Ludovica Zaccagnini $^{1} \cdot$ Amber Wallis $^{1} \cdot$ Kristina Zhelcheska $^{3} \cdot$ Nora Kim $^{4}$. \\ John Sanderson ${ }^{5} \cdot$ Haiyang Jiang ${ }^{6}$. Elodie Martin ${ }^{1} \cdot$ Adam Cantlon $^{6} \cdot$ Matteo Rovere $^{7} \cdot$ Lei Liu $^{6} \cdot$ Marc Sylvester $^{8}$. \\ Tammaryn Lashley ${ }^{9} \cdot$ Ulf Dettmer $^{6} \cdot$ Zane Jaunmuktane $^{9,10,11} \cdot$ Tim Bartels $^{1}$ (D)
}

Received: 28 September 2021 / Revised: 12 January 2022 / Accepted: 1 February 2022 / Published online: 9 February 2022

(c) The Author(s) 2022

\begin{abstract}
The protein $\alpha$-synuclein, a key player in Parkinson's disease (PD) and other synucleinopathies, exists in different physiological conformations: cytosolic unfolded aggregation-prone monomers and helical aggregation-resistant multimers. It has been shown that familial PD-associated missense mutations within the $\alpha$-synuclein gene destabilize the conformer equilibrium of physiologic $\alpha$-synuclein in favor of unfolded monomers. Here, we characterized the relative levels of unfolded and helical forms of cytosolic $\alpha$-synuclein in post-mortem human brain tissue and showed that the equilibrium of $\alpha$-synuclein conformations is destabilized in sporadic PD and DLB patients. This disturbed equilibrium is decreased in a brain region-specific manner in patient samples pointing toward a possible "prion-like" propagation of the underlying pathology and forms distinct disease-specific patterns in the two different synucleinopathies. We are also able to show that a destabilization of multimers mechanistically leads to increased levels of insoluble, pathological $\alpha$-synuclein, while pharmacological stabilization of multimers leads to a "prion-like" aggregation resistance. Together, our findings suggest that these disease-specific patterns of $\alpha$-synuclein multimer destabilization in sporadic PD and DLB are caused by both regional neuronal vulnerability and "prion-like" aggregation transmission enabled by the destabilization of local endogenous $\alpha$-synuclein protein.
\end{abstract}

Keywords $\alpha$-Synuclein $\cdot$ PD $\cdot$ DLB $\cdot$ Multimers $\cdot$ Aggregation $\cdot$ Aggregation transmission

\section{Introduction}

The protein $\alpha$-synuclein $(\alpha S)$ is the major constituent of pathological neuronal inclusions both in Parkinson's disease (PD) and dementia with Lewy bodies (DLB) [56].

Tim Bartels

t.bartels@ucl.ac.uk

1 Dementia Research Institute, University College London, London, UK

2 Institute of Aerospace Medicine, German Aerospace Center, Cologne, Germany

3 Department of Neuromuscular Diseases, UCL Queen Square Institute of Neurology, London, UK

4 Department of Neurosurgery, NYU Grossman School of Medicine, New York, NY, USA

5 Department of Neurology, UW Medicine, Seattle, WA, USA

6 Ann Romney Center for Neurologic Diseases, Brigham and Women's Hospital, Harvard Medical School, Boston, MA, USA
Despite initially being characterized as natively unfolded, data collected in the last decade suggest that $\alpha \mathrm{S}$ can exhibit different conformations under physiological conditions, which in turn help in governing aggregation propensity. The cytosolic unfolded, monomeric form of $\alpha \mathrm{S}\left(\alpha \mathrm{S}^{\mathrm{U}}\right)$ is

7 Department of Medical Sciences, University of Turin, Turin, Italy

8 Medical Faculty, Core Facility Mass Spectrometry, Institute of Biochemistry and Molecular Biology, University of Bonn, Bonn, Germany

9 Division of Neuropathology, National Hospital for Neurology and Neurosurgery, University College London NHS Foundation Trust, Queen Square, London, UK

10 Queen Square Brain Bank for Neurological Disorders, UCL Queen Square Institute of Neurology, Queen Square, London, UK

11 Department of Clinical and Movement Neurosciences, University College London, London, UK 
aggregation prone and can misfold into soluble, toxic oligomers, protofilaments, and amyloid fibrils, forms that are associated with pathology. The unfolded $\alpha \mathrm{S}^{\mathrm{U}}$ form, initially described in the literature as the only physiological species, exhibits spontaneous aggregation dependent on increased protein concentrations or long incubations into the pathological amyloid fibrillar form $\left(\alpha \mathrm{S}^{\mathrm{F}}\right)$, a pathological hallmark of synucleinopathies [36, 43]. Conversely, the cytosolic helically folded, multimeric form $\left(\alpha \mathrm{S}^{\mathrm{H}}\right)$ resists disease-associated changes [4, 59]. Our and several other laboratories have demonstrated that physiological $\alpha \mathrm{S}^{\mathrm{H}}$ (mainly tetramers and lower abundance related hexamers and octamers) exhibits enhanced aggregation resistance, plays a role in synaptic vesicle release and inversely correlates with various genetic PD risk factors $[2,4,9$, $12-15,19,21,22,26,29,30,33,38,44-46,49,59,61$, 62]. Different techniques have been applied to prove the presence and analyze the structural identities, composition and aggregation properties of $\alpha \mathrm{S}^{\mathrm{H}}$ and $\alpha \mathrm{S}^{\mathrm{U}}$ in in vitro, ex vivo and in vivo models, e.g., non-denaturing Blue Native PAGE [4, 9, 22, 23, 59] and Clear Native PAGE [4], sedimentation equilibrium analytical ultracentrifugation [4, 14], gel filtration [9], YFP complementation [14], single particle electron microscopy [59], solution nuclear magnetic resonance [26, 59], high-resolution single-molecule force spectroscopy [44] or mass spectrometry [14, $22,23,59]$. Moreover, $\alpha \mathrm{S}^{\mathrm{H}}$ stabilizing drugs [30, 45] have recently begun to enter clinical trials.

Accumulation of fibrillar $\alpha S^{\mathrm{F}}$ in patients with PD with newly grafted neurons has been demonstrated in $2008 / 2009$ [34, 35], implying that $\alpha S^{\mathrm{F}}$ can spread from disease-affected to healthy tissue in a "prion-like" fashion. The templating "prion-like" properties of $\alpha S^{\mathrm{F}}$ have been analyzed in various papers using different $\alpha \mathrm{S}$ seeds (e.g., oligomers, recombinant $\alpha \mathrm{S}$, human brain homogenate, aggregated $\alpha \mathrm{S}$, preformed fibrils), target tissues and cells (e.g., CSF, olfactory mucosa, skin tissue, brain tissue, glial cells) in different sporadic and genetic synucleinopathies $[3,6,7,10,16,18,24,25,28,31,37,39,40,47,48,50$, $52,53,55,60]$.

However, whether this "prion-like" mechanism of a single protein can indeed lead to three distinct clinical diseases [PD, DLB, and multiple system atrophy (MSA)] is still unknown. Here, we show how local vulnerability of different brain regions, characterized by imbalances in the two physiological forms $\alpha \mathrm{S}^{\mathrm{U}}$ and $\alpha \mathrm{S}^{\mathrm{H}}$, contribute to the development of $\alpha$-synucleinopathies. Our data presented here allow for the first time to explain region-specific vulnerability, patient stratification and how to potentially counteract "prion-like" aggregation transmission of $\alpha \mathrm{S}$ through pharmacological stabilization of physiologically helical $\alpha \mathrm{S}^{\mathrm{H}}$.

\section{Materials and methods}

\section{Brain samples}

The experimental use of human brain samples was approved under the protocol number RA032611/1 by the University College London and the REC reference 18/LO/0721 ('Queen Square Brain Bank for Neurological Disorders').

\section{cDNA cloning}

Single-mutation $\alpha \mathrm{S}$ expression plasmids were generated from the pcDNA4 or pcDNA3/aS plasmid9 using the QuikChange II site-directed mutagenesis kit and appropriate primers.

\section{Cell lines and transfection}

Cells were cultured at $37^{\circ} \mathrm{C}$ in $5 \% \mathrm{CO}_{2}$. Human BE(2)-M17 neuroblastoma cells (called M17D, ATCC number CRL2267) were cultured in DMEM/F12 GlutaMAX (Thermo Fisher Scientific), 10\% fetal bovine serum (Sigma) and $1 \%$ penicillin/streptomycin. Prior to the transfection, cells were seeded at a density of $1.5 \times 106$ cells $/ 6 \mathrm{~cm}$ dish. HEK cells were cultured in DMEM with $10 \%$ fetal bovine serum (Thermo Fisher Scientific) and 1\% penicillin/streptomycin and L-glutamine ( $2 \mathrm{mM}$, Gibco). Transfections with $\alpha \mathrm{S}$ wild type and fPD mutants (A30P, E46K, G51D, A53T, H50Q) were carried out using Lipofectamine 2000 according to the manufacturer's instructions. Cells were harvested $48 \mathrm{~h}$ after transfection, pelleted, snap frozen and further processed by cross-linking. HEK293 $\alpha$ S C-term Strep II-tagged lysates were purchased from GeneScript.

\section{Protein extraction}

Frozen brain or cell pellet samples were manually homogenized in $1 \times \mathrm{PBS} /$ protease inhibitor/phosphatase inhibitor (Sigma, Thermo Fisher Scientific). Tissue suspensions were lysed by sonication (Sonic Dismembrator model 300, setting 40 for $15 \mathrm{~s}$ at $4{ }^{\circ} \mathrm{C}$ or Fisher Scientific Model 705 Sonic Dismembrator, sonication of amplitude $5 \%$ for $15 \mathrm{~s}$ at $4{ }^{\circ} \mathrm{C}$ ). Samples were ultracentrifuged at $100,000 \mathrm{~g}$ for $1 \mathrm{~h}$ at $4{ }^{\circ} \mathrm{C}$. The resultant supernatant contained soluble proteins. To separate membrane proteins from insoluble proteins, the pellet from the homogenized brain tissue was resuspended in $1 \mathrm{ml}$ OG-RIPA buffer $(0.5 \%$ Nonidet P-40 substitute (NP-40, Pan Reac), 0.5\% sodium deoxycholate (Sigma), $0.1 \%$ sodium dodecyl sulfate (SDS, Sigma), and $10 \mathrm{mM}$ calcium chloride dihydrate (Sigma) with $2 \% n$-octyl- $\beta$-D-glucoside (abcam) and centrifuged at $175,000 \mathrm{~g}$ for $30 \mathrm{~min}$ at $4{ }^{\circ} \mathrm{C}$. The supernatant containing 
membrane-associated proteins was collected. The remaining pellet containing insoluble proteins was resuspended in $200 \mu \mathrm{l} 8 \mathrm{M}$ urea (Sigma)/5\% SDS (Sigma)/PBS (Sigma),

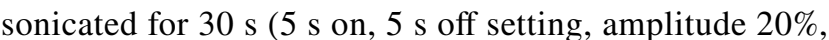
room temperature (RT), Fisher Scientific Model 705 Sonic Dismembrator), and boiled for $10 \mathrm{~min}$ at $100{ }^{\circ} \mathrm{C}$. Protein concentrations were measured with the Pierce BCA protein assay kit (Thermo Fisher Scientific) according to the manufacturer's instructions.

\section{Purification of aS from erythrocytes}

Freshly collected and washed erythrocytes were resuspended in threefold volume of ACK lysing buffer (Lonza, Walkersville $\mathrm{MD}$, USA). $\left(\mathrm{NH}_{4}\right)_{2} \mathrm{SO}_{4}$ to a final concentration of $25 \%$ was added and incubated at $4{ }^{\circ} \mathrm{C}$ for $30 \mathrm{~min}$. The lysate was centrifuged $(20,000 \mathrm{~g}, 20 \mathrm{~min})$, and the supernatant brought up to $50 \%\left(\mathrm{NH}_{4}\right)_{2} \mathrm{SO}_{4}$. The pellet was washed several times in $55 \%\left(\mathrm{NH}_{4}\right)_{2} \mathrm{SO}_{4}$ to remove excess hemoglobin. The sample was centrifuged at $20,000 \mathrm{~g}$ for $20 \mathrm{~min}$ and the pellet resolubilized in 50-fold volume of $50 \mathrm{mM}$ phosphate buffer, $\mathrm{pH}$ 7.0, $1 \mathrm{M}\left(\mathrm{NH}_{4}\right)_{2} \mathrm{SO}_{4}$. Five millilitre of the resultant solution was injected onto a $5 \mathrm{ml}$ HiTrap phenyl hydrophobic interaction column (GE Healthcare) equilibrated with $50 \mathrm{mM}$ phosphate buffer, $\mathrm{pH} 7.0,1 \mathrm{M}\left(\mathrm{NH}_{4}\right)_{2} \mathrm{SO}_{4}$. $\alpha \mathrm{S}$ was eluted with a 1-0 M $\left(\mathrm{NH}_{4}\right)_{2} \mathrm{SO}_{4}$ gradient in $50 \mathrm{mM}$ phosphate buffer, $\mathrm{pH}$ $7.0\left(\alpha \mathrm{S}\right.$ eluted at $\left.\sim 0.75 \mathrm{M}\left(\mathrm{NH}_{4}\right)_{2} \mathrm{SO}_{4}\right)$.

\section{Cross-linking of lysate}

Twenty microgram of total protein in a total volume of $25 \mu \mathrm{l}$ was incubated with $10 \mu \mathrm{l} 5 \mathrm{mM}$ DSG (Thermo Fisher Scientific, final concentration $1.43 \mathrm{mM}$, DSG was first dissolved in $50 \mu \mathrm{l}$ of anhydrous DMSO and further in PBS pH 7.4 to a final volume of $1 \mathrm{ml}$ ) for $30 \mathrm{~min}$ at $37^{\circ} \mathrm{C}$ shaking or rotating. The reaction was quenched with $3.5 \mu 11 \mathrm{M}$ Tris-HCl, pH 7.6 (Sigma), for 5 min shaking at RT. Samples were analyzed in biological duplicates and technical triplicates. The cross-linker disuccinimidyl suberate (DSS, Thermo Scientific Pierce) was used for validation.

\section{Immunoblotting (Western blot, WB)}

Samples were boiled at $90{ }^{\circ} \mathrm{C}$ in $10 \mu \mathrm{l} 4 \times$ NuPage LDS sample buffer (Novex)/1:10 $\beta$-mercaptoethanol (Sigma) for 5 min. Samples were electrophoresed at maximum $200 \mathrm{~V}$ on NuPAGE Bis Tris Midi gels (Invitrogen) with NuPage MES-SDS running buffer (Invitrogen) and the SeeBlue Plus2 pre-stained molecular weight marker (Invitrogen). The total volume of each sample containing $20 \mu \mathrm{g}$ total protein was loaded on each lane. After electrophoresis, gels were incubated in 20\% ethanol (Decon Laboratories) for $5 \mathrm{~min}$ at RT and electroblotted onto iBlot 2 NC Regular Stacks (Invitrogen) using the iBlot Dry Blotting preset 7 min blotting program. The membrane was briefly rinsed in ultrapure water and incubated in 4\% paraformaldehyde/PBS (Alfa Aesar) for $30 \mathrm{~min}$ at RT. Some membranes were stained with $0.1 \%$ Ponceau (Biotium) and rinsed with ultrapure water. Membranes were blocked in Odyssey blocking buffer (PBS)/ PBS buffer 1:1 (LI-COR) or casein buffer 0.5\% (BioRad) for $30 \mathrm{~min}$ at RT. After blocking, membranes were incubated with primary antibodies overnight at $4{ }^{\circ} \mathrm{C}$. Membranes were briefly rinsed in PBS-Tween $0.1 \%$ and then washed $3 \times 10 \mathrm{~min}$ in PBS-Tween $0.1 \%$. Membranes were incubated with the corresponding secondary LI-COR antibodies (1:20,000 in Odyssey blocking buffer (PBS)/PBS 1:1/Tween $0.1 \%$ at RT for $1 \mathrm{~h}$ in the dark). Membranes were briefly rinsed in PBS-Tween $0.1 \%$ and then washed $3 \times 10 \mathrm{~min}$ in PBS-Tween $0.1 \%$ in the dark. Membranes were imaged on a LI-COR Odyssey CLx imaging system (settings: custom, western, quality low, resolution $169 \mu \mathrm{M}$, focus offset 0.0 , auto intensity).

\section{Antibodies}

Antibodies used were $2 \mathrm{~F} 12$ to $\alpha \mathrm{S}[12]$ (MABN1817, Merck, WB 1:5000), SOY1 to $\alpha$ S (MABN1818, Merck), and antiDJ-1 [5] (or GeneTex, WB 1:2000). Anti-Tau (EP2456Y, abcam, WB 1:5000), anti- $\beta$ tubulin III (T2200, SigmaAldrich, WB 1:5000), anti-heat shock protein 70 (HSP70, ab181606, abcam, WB 1:1000), anti-14-3-3 beta (ab15260, abcam, WB 1:500), anti- $\beta$ actin (ab8227, Abcam, WB 1:5000), and anti-HSP90 (HEK: ab clone 16F1, ADISPA-83, Enzo, WB 1:1000, huBrain: ab PA3-013, Invitrogen, WB 1:500).

\section{aS-specific ELISA}

Multi-array $96 \mathrm{HB}$ plates (MSD) were coated with the capture antibody anti- $\alpha$ S $2 \mathrm{~F} 12$ (200 ng 2F12[12] in PBS, $30 \mu \mathrm{l} /$ well) and incubated over night at $4{ }^{\circ} \mathrm{C}$. The next day, the remaining liquid was removed, and the plates were blocked with 5\% Blocker A (MSD) in PBS-Tween 0.1\% (150 $\mu \mathrm{l} /$ well, Sigma) shaking for $2 \mathrm{~h}$ at RT. Plates were washed $5 \times$ with PBS-Tween $0.1 \%(150 \mu \mathrm{l} /$ well). Standards (recombinant $\alpha \mathrm{S}$, highest concentration $1 \mathrm{ng}$, ratio for serial dilution 1:4, $30 \mu \mathrm{l} /$ well $)$ and protein $(30 \mu \mathrm{l} /$ well, soluble protein fraction 1:500, membrane (OG-RIPA) and insoluble (UREA/SDS fraction 1:100) were diluted in 1\% Blocker A in PBS-Tween $0.1 \%$ and the plates were incubated shaking for $2 \mathrm{~h}$ at RT. The remaining liquid was removed and the plates were washed $5 \times$ with PBS-Tween $0.1 \%(150 \mu \mathrm{l} /$ well $)$. The sulfo-tagged detection antibody SOY1 (50 ng SOY1 in 1\% Blocker A (MSD)/PBS-Tween 
$0.1 \%, 30 \mu \mathrm{l} /$ well) was added and the plate incubated shaking for $1 \mathrm{~h}$ at $\mathrm{RT}$ in the dark. The remaining liquid was removed, and the plates were washed $5 \times$ with PBS-Tween $0.1 \%(150 \mu \mathrm{l} /$ well). $2 \times$ read buffer (MSD)/MilliQ water was added ( $150 \mu \mathrm{l} /$ well $)$ and the plates were immediately measured using an MSD Sector 2400 imager or MSD Model No. 1300, QuickPlex SQ 120 according to the manufacturer's instructions. All samples and standards were analyzed in technical duplicates.

\section{Immunoprecipitation of aS}

$\alpha \mathrm{S}$ from brain tissue was immunoprecipitated using the Pierce Direct IP Kit (Thermo Fisher Scientific) according to the manufacturer's instructions. The $2 \mathrm{~F} 12$ to $\alpha \mathrm{S}[12]$ was used as a capture antibody ( $300 \mu \mathrm{g} /$ reaction). At least, $800 \mu \mathrm{g}$ total protein was used for each cross-linking of lysate reaction using $5 \mathrm{mM}$ DSG (final concentration in total volume $1.43 \mathrm{mM}$ ). Volumes of wash and incubation buffers were adapted to the total volume input of the sample. Elution fractions were further concentrated using Amicon concentration columns (Millipore) according to the manufacturer's instructions. The fractions were checked for the presence of $\alpha \mathrm{S}$ monomer and multimer using immunoblotting and Coomassie staining. Negative controls included the incubation and clearance of samples using the Pierce Control Agarose Resin (nonamine reactive) and the incubation of samples on the AminoLink Plus ${ }^{\mathrm{TM}}$ Coupling Resin column without any antibody. Normal mouse IgG was used as a positive control (200 $\mu \mathrm{g} /$ AminoLink Plus ${ }^{\mathrm{TM}}$ Coupling Resin column, sc-2025, Santa Cruz Biotechnology). $\alpha$ S from HEK293 $\alpha S$ C-term Strep II-tagged lysates was immunoprecipitated using StrepTrap $5 \mathrm{ml}$ columns. Briefly, cells were lysed, ultracentrifuged $\left(100,000 \mathrm{~g}\right.$ at $4{ }^{\circ} \mathrm{C}$ for $\left.1 \mathrm{~h}\right)$ and the protein content measured in the supernatant. Cross-linking was performed according to the protocol above and the cross-linked lysate was loaded onto equilibrated Strep Tag $5 \mathrm{ml}$ columns. Unbound samples were washed out with PBS buffer, $\mathrm{pH} 7.4$, and the sample eluted with elution buffer (2.5 mM desthiobiotin in PBS, $\mathrm{pH}$ 7.4). For mock controls, HEK without $\alpha \mathrm{S}$ tag were subjected to immunoprecipitation.

\section{Size exclusion chromatography (SEC)}

Immunoprecipitated $\alpha \mathrm{S}$ fractions were injected on a Superdex 200 (10/300 GL) column (GE Healthcare) at room temperature and eluted with $50 \mathrm{mM} \mathrm{NH} 4 \mathrm{Ac}(\mathrm{pH} 7.4)$ while measuring (in-line) the conductivity and the 280-nm absorption of the eluate at $0.7 \mathrm{ml} / \mathrm{min}$. For size estimation, a gel filtration standard (Bio-Rad) was run on the column, and the calibration curve was obtained by semilogarithmic plotting of molecular weight versus the elution volume divided by the void volume. Immunoblotting was performed to identify the fractions containing $\alpha \mathrm{S}$ multimers and monomers.

\section{Circular dichroism spectroscopy (CDS)}

After SEC separation, samples containing $\alpha \mathrm{S}$ multimers or monomers were exchanged into $10 \mathrm{mM}$ ammonium acetate using Zeba spin desalting columns (Thermo Fisher), lyophilized, and resuspended in $10 \mathrm{mM}$ ammonium acetate at a concentration of approximately $10 \mu \mathrm{M} . \alpha \mathrm{S}$ samples were added to a $1 \mathrm{mM}$ path length quartz cuvette for far-UV CD and analyzed using a J-1500 CD spectrometer (Jasco) at $25^{\circ} \mathrm{C}$. Temperature control with an accuracy of $0.1^{\circ} \mathrm{C}$ was achieved with a heating/cooling accessory equipped with a Peltier element (PFD-425S) connected to a water thermostatic bath. Buffer spectra were recorded and subtracted.

\section{Multi-angled light scattering (MALS)}

Immunoprecipitated and SEC-separated $\alpha \mathrm{S}$ multimers and monomers were loaded at a flow rate of $0.15 \mathrm{ml} / \mathrm{min}$ onto a Superdex 200 3.2/300 GL Increase column (GE Healthcare) previously equilibrated in $50 \mathrm{mM}$ ammonium acetate, $\mathrm{pH}$ 7.4. The column was connected in line to a Dawn $8+$ MALS detector (Wyatt Technology) using a laser emitting at $690 \mathrm{nM}$ and by refractive index measurement using an Optilab T-rex (Wyatt Technology Corp.).

\section{PFF generation}

Five milligram per millilitre recombinant $\alpha \mathrm{S}$ in PBS was aggregated for 3 days at $37^{\circ} \mathrm{C}$ with nutation to form thioflavin T-positive fibrils. To generate soluble PFFs, $\alpha \mathrm{S}$ fibrils were diluted to $1 \mathrm{mg} / \mathrm{ml}$ and sonicated at power level 50 for $3 \times 10$ s using a Sonic Dismembrator model 300 (Fisher). Aliquots of the resultant material were flash-frozen in liquid nitrogen and stored at $-80^{\circ} \mathrm{C}$.

\section{Preformed fibril (PFF) transfection}

All reagents were purchased from Thermo Fisher Scientific unless otherwise noted. Transfected M17D were incubated with $0.5 \mu \mathrm{g} / \mathrm{ml} \alpha \mathrm{S}$ PFF. After $48 \mathrm{~h}$, the medium was aspirated, and cells were harvested by scraping and washed $2 \times$ in cold PBS (500 $g$ spin for $5 \mathrm{~min}$ ). Cell pellets were resuspended in $1 \times \mathrm{PBS} /$ protease inhibitor and sonicated with a Sonic Dismembrator model 300 (microtip setting $40 ; 2 \times 15 \mathrm{~s}$ ). Cells were spun at $20,000 \mathrm{~g}$ for 10 min. The supernatant was kept ("cytosol") and the pellet was incubated in $1 \%$ Triton $\mathrm{X}-100$ at $4{ }^{\circ} \mathrm{C}$ for $30 \mathrm{~min}$ under nutation. After a $20,000 \mathrm{~g}$ spin for $10 \mathrm{~min}$, 
the supernatant was kept ("membrane fraction") and the pellet dissolved in $5 \% \mathrm{SDS}$ at $100{ }^{\circ} \mathrm{C}$ for $10 \mathrm{~min}$ to give the "insoluble $\alpha \mathrm{S}$ " fraction. Relative $\alpha \mathrm{S}$ content in each fraction was analyzed by SDS-PAGE/Western blot and ELISA. For the SCDi experiments, M17D/ $\alpha S-W T:: Y F P[30]$ cells were monitored on an IncuCyte Zoom machine (Essen Bioscience). Cells were seeded at a density of $0.1 * 10^{\circ} 6$ cells $/ \mathrm{ml}$ in a 12 -well plate. Twenty-four hours after seeding, a fraction of the cells was treated with $10 \mu \mathrm{M}$ SCDi or DMSO. Twenty-four hours after the treatment, some cells were seeded with $0.5 \mu \mathrm{g} / \mathrm{ml} \alpha \mathrm{S}^{\mathrm{F}}$. Another $48 \mathrm{~h}$ and $96 \mathrm{~h}$ after seeding, SCDi or DMSO was added again. The experiments were carried out in biological duplicates. The IncuCyte settings and analysis were performed analogous to Imberdis et al. [30]. For the seeding experiment, M17D human neuroblastoma cells constitutively expressing wt $\alpha \mathrm{S}$ were analyzed in biological and technical duplicates, and crosslinking was performed analogous to brain samples. Cells were seeded at a density of $0.1^{*} 10^{\circ} 6$ cells $/ \mathrm{ml}$ in a 12 -well plate. Twenty-four hours after seeding, some cells were seeded with $0.5 \mu \mathrm{g} / \mathrm{ml} \alpha \mathrm{S}^{\mathrm{F}}$.

\section{Thioflavin T (ThT) binding}

To detect amyloid fibril growth, a discontinuous assay was used. Aliquots $(10 \mu \mathrm{l})$ were removed from each purified $\alpha \mathrm{S}$ sample (lyophilized from $50 \mathrm{mM}$ ammonium acetate, $\mathrm{pH} 7.4$, and agitated at $37{ }^{\circ} \mathrm{C}$ at a concentration of $75 \mu \mathrm{M}$ in $20 \mathrm{mM}$ Bis-Tris propane, $100 \mathrm{mM} \mathrm{LiCl}, \mathrm{pH}$ 7.4) and added to $2 \mathrm{ml}$ of a $10 \mu \mathrm{M}$ thioflavin $\mathrm{T}$ (ThT) solution in $10 \mathrm{mM}$ glycine buffer, $\mathrm{pH} 9$. Fluorescence was directly quantified on a Varian Eclipse fluorescence spectrophotometer at $20{ }^{\circ} \mathrm{C}$ by exciting at $444 \mathrm{nM}$ and scanning the emission wavelengths from 460 to $550 \mathrm{nM}$ with slit widths set at $5 \mathrm{nM}$ (PMT at $750 \mathrm{~V})$.

\section{Mass spectrometry}

HEK293 $\alpha$ S C-term Strep II-tagged lysates were crosslinked and immunoprecipitated as described above and the $\alpha S^{\mathrm{H}}$ and $\alpha \mathrm{S}^{\mathrm{U}}$ were separated via SEC and run on an SDS-gel. Gel pieces containing the bands of interest were cut out and lyophilized prior to mass spectrometry analysis. Gel slices were subjected to gel digestion. In brief, slices were washed consecutively with water, $50 \%$ acetonitrile (ACN), and $100 \%$ ACN. Proteins were reduced with $20 \mathrm{mM}$ DTT in $50 \mathrm{mM}$ ammonium bicarbonate and alkylated with $40 \mathrm{mM}$ acrylamide (in
$50 \mathrm{mM}$ bicarbonate). The slices were washed again and dehydrated with ACN. Proteolysis was performed with 330 ng chymotrypsin or trypsin (sequencing grade Promega, Mannheim, Germany) at $37{ }^{\circ} \mathrm{C}$ overnight. The peptide extracts were dried in a vacuum concentrator and stored at $-20{ }^{\circ} \mathrm{C}$. Dried peptides were dissolved in $10 \mu \mathrm{l} 0.1 \%$ formic acid (solvent A). Two microlitres was injected onto a $\mathrm{C} 18$ analytical column (self-packed $300 \mathrm{mM}$ length, $100 \mu \mathrm{M}$ inner diameter, ReproSil-Pur 120 C18-AQ, $3 \mu \mathrm{M}$, Dr. Maisch GmbH, AmmerbuchEntringen, Germany). Peptides were separated during a linear gradient from 2 to $35 \%$ solvent B (90\% acetonitrile, $0.1 \%$ formic acid) within 90 min at a flow rate of $300 \mathrm{nl} / \mathrm{min}$. The nanoHPLC was coupled online to an Orbitrap Lumos mass spectrometer (Thermo Fisher Scientific, Bremen, Germany). Peptide ions between 330 and $1600 \mathrm{~m} / \mathrm{z}$ were scanned in the Orbitrap detector with a resolution of 60,000 (maximum injection time $50 \mathrm{~ms}$, AGC target 400,000). Precursor ions (threshold 25,000) were subjected to higher energy collision-induced dissociation within a $2.5 \mathrm{~s}$ cycle and fragments were analyzed in the Orbitrap detector (maximum injection time $22 \mathrm{~ms}$, resolution $=15,000$ ). Fragmented peptide ions were excluded from repeat analysis for $15 \mathrm{~s}$.

\section{Semiquantitative Lewy body score}

Lewy body pathology density was assessed semiquantitatively on formalin-fixed paraffin-embedded tissues at $20 \times$ magnification (Leica DM3000 microscope), using revised McKeith staging scheme of $\alpha \mathrm{S}$ pathology [42], with the stages ranging from 0.5 to 4 . Stage 0.5 was assigned if a single Lewy body was seen in a region of interest after screening several nearby fields. Stage 1 was assigned if a single Lewy body was consistently seen per each field after screening several nearby fields, and Stage 1.5 if a single Lewy body was seen per field with rare additional two Lewy bodies per single nearby field. Stage 2 was assigned if two to three Lewy bodies were seen per field, and Stage 2.5, if twio to three Lewy bodies were seen per field and rare additional four Lewy bodies per nearby field. Stage 3 was assigned if 4-10 Lewy bodies were consistently seen per field and Stage 3.5, if 11-20 Lewy bodies were seen per field. Stage 4 was assigned if more than 20 Lewy bodies were seen per field. The following anatomical regions were assessed: amygdala, transentorhinal cortex, peri- and parastriate cortex, and cortical regions of the insula, anterior cingulate gyrus, middle temporal gyrus, Heschl's gyrus, anterior middle frontal gyrus, and inferior parietal lobule. 


\section{Protein ratio determination and statistics}

Western Blot: the ratio of protein multimers to monomers was analyzed using the Image Studio software western analysis according to the manufacturer's instructions (background subtraction: median, border with 3, top/bottom). Data analysis (except for correlation and regression analysis) was performed using GraphPad Prism 7 (GraphPad Software, La Jolla, CA, USA). Statistical significance was determined by Mann-Whitney test $(p<0.05$, two-tailed). Samples are displayed as mean \pm SD. Linear regression analysis was performed using R. Additional R software packages included "devtools" (https://github. com/r-lib/devtools), "easyGgplot2" (https://github.com/ kassambara/easyGgplot2) and "Hmisc" (https://github. com/harrelfe/Hmisc). Samples were coded as follows. Gender: male $=1$, female $=2$. McKeith: neocortical $=3$, limbic $=2$, brainstem $=1$, controls (no McKeith staging) were set to 0. CERAD: none $=0$, sparse $=1$, mild $=2$, moderate $=3$, frequent $=4$. Braak LB staging: controls were set to 0, PD and DLB patients were coded according to evaluated Braak LB staging. ELISA: raw data from the MSD Discovery Workbench was imported into Excel 2010 (Microsoft) for background calculation and subtraction. Values from Excel were imported into GraphPad Prism 7 (GraphPad Software, La Jolla, CA, USA) for interpolation together with the known standard concentrations (standard curve: sigmoidal, 4PL, $\mathrm{X}$ is $\log$ (concentration, no special handling for outliers). The final concentration of each analyzed sample was calculated in Excel according to the dilution factor. Mass spectrometry: raw data processing and analysis of database searches were performed with Proteome Discoverer software 2.4.0.305 (Thermo Fisher Scientific). The protein-specific peptide identification was done with an in-house Mascot server version 2.6.1 (Matrix Science Ltd, London, UK) from Proteome Discoverer. MS2 data were searched against a database of common contaminants (cRAP of the Global Proteome Machine), and human SwissProt sequences. Precursor ion $\mathrm{m} / \mathrm{z}$ tolerance was $10 \mathrm{ppm}$, and fragment ion tolerance $0.02 \mathrm{Da}$. Tryptic peptides with up to two missed cleavages were searched, propionamide was set as a static modification of cysteines, and oxidation as a dynamic modification of methionine. Mascot results from searches against SwissProt were sent to the Percolator algorithm_ENREF_3 version 3.02 as implemented in Proteome Discoverer 2.4. If the data did not permit use of Percolator, PSMs were evaluated by a target-decoy procedure. Spectra without high confidence (FDR 1\%) matches were sent to a second round Mascot search with semi-specific enzyme cleavage. The false discovery rate of proteins in these samples was $0.6 \%$.

\section{Results}

\section{a-Synuclein exists in human brain in an equilibrium between helically folded homo-multimeric and unfolded monomeric species}

To address the question of whether the equilibrium of $\alpha \mathrm{S}^{\mathrm{U}}$ and $\alpha \mathrm{S}^{\mathrm{H}}$ also plays an important role in sporadic synucleinopathies, we adapted our established [4, 12, 29] multimer assay (using cross-linking and Western blot analysis of lysate) for frozen human post-mortem tissue (Online Resource Figs. 1, 2, 3, 4, 5). This protocol revealed a prominent cytosolic $\sim 80 \mathrm{kDa}$ and $14 \mathrm{kDa} \alpha \mathrm{S}$ species (Fig. 1a; Online Resource Figs. 2, 3, 4, 5) as described previously $[12,29,38]$. The two cytosolic $\alpha \mathrm{S}$ species corresponded to a $86 \mathrm{kDa}$ helically folded homo-multimer and a $14 \mathrm{kDa}$ monomer, respectively, as confirmed by circular dichroism (CD) spectroscopy, Multi-angle light scattering and Western blotting were conducted on purified $14 \mathrm{kDa}$ and $86 \mathrm{kDa}$ species from human brain tissue and HEK cells (Fig. 1a, b, f; Online Resource Figs. 6, 7). Mass spectrometry and Western Blot analysis of the $86 \mathrm{kDa}$ species showed only the presence of $\alpha \mathrm{S}$ compared to controls, indicating its homo-multimeric nature (Online Resource Table 1, Online Resource Figs. 8, $9,10,11)$. We confirmed that the cross-linking procedure did not lead to an artificial production of $\alpha \mathrm{S}^{\mathrm{H}}$ using recombinant $E$. coli-derived protein in contrast to brain tissue (which led only to cross-linked $\alpha \mathrm{S}^{\mathrm{U}}$ ), HEK cells or red blood cells (yielding cross-linked $\alpha \mathrm{S}^{\mathrm{H}}$ ) and non-denaturing purification from both human tissue and bacterial cells (leading to the same species obtained under cross-linking conditions, Fig. 1c-e). Figure 1 shows the biophysical analysis of physiological $\alpha \mathrm{S}$ found in the cytosol. Insoluble or amyloid-type aggregated forms of pathological $\alpha \mathrm{S}$ are not found in the cytosol (they represent typically only $\sim 0.5 \%$ of total protein in this subcellular compartment) as we have shown before in human brain [54]) and are therefore not displayed.

\section{The equilibriums of cytosolic helically folded and unfolded physiological aS is disturbed in PD and DLB patients}

Next, we assessed the ratio of cytosolic helical and unfolded $\alpha \mathrm{S}\left(\alpha \mathrm{S}^{\mathrm{H}} / \alpha \mathrm{S}^{\mathrm{U}}\right)$ in four different brain regions (entorhinal cortex, cingulate cortex, frontal cortex and striatum) of 28 agematched individuals, classified as neurological controls, 15 DLB patients and 15 sporadic PD patients (Table 1). Representative pictures of Western blot analyses from controls and DLB and PD patients are displayed in Fig. 2a and Online Resource Fig. 12.

We found that DLB patients exhibited a significant reduction of $\alpha \mathrm{S}^{\mathrm{H}} / \alpha \mathrm{S}^{\mathrm{U}}$ in the frontal cortex $(p<0.001$, Fig. $2 b)$ 
a Immunoprecipitated and separated (SEC) $\alpha S^{H}$ and $\alpha S^{U}$

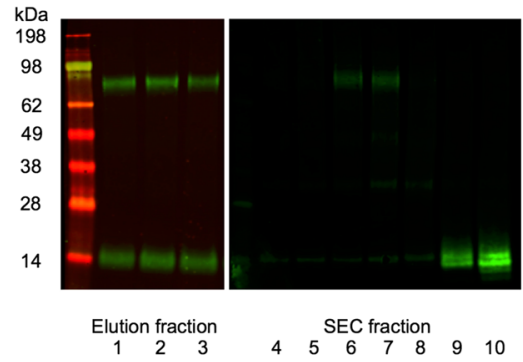

d CD spectra from HEK cell- and brainderived crosslinked $\alpha \mathrm{S}^{\mathrm{H}}$ and red blood cell (RBC)-derived native $\alpha \mathrm{S}^{\mathrm{H}}$

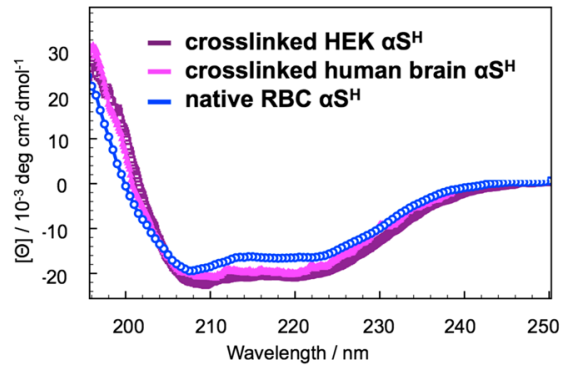

b CD spectra from brain-derived crosslinked $\alpha S^{\mathrm{H}}$ and $\alpha S^{\mathrm{U}}$

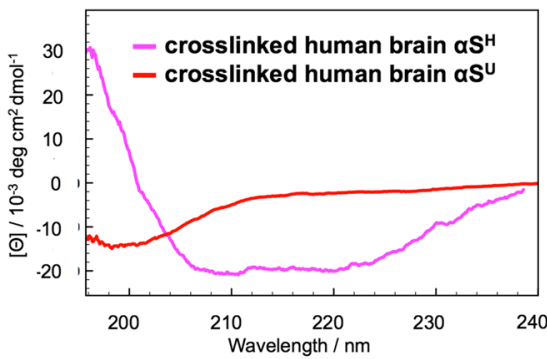

c CD spectra from E. coli-derived native and crosslinked $\alpha S^{U}$

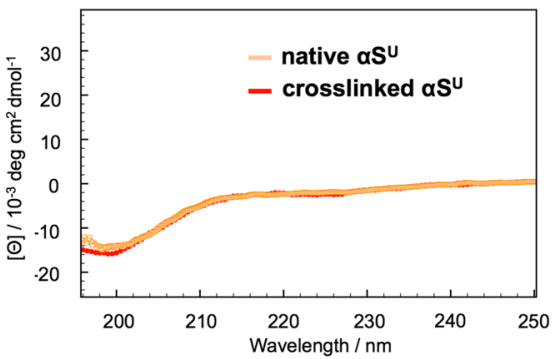

e Folded structure upon crosslinking of human- and E. coli-derived aS

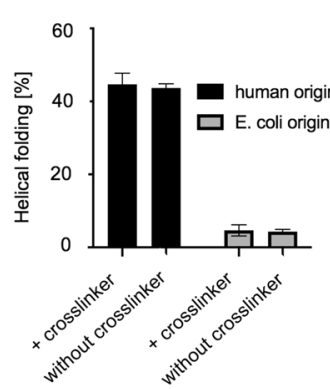

f Multi-angle light scattering of $\alpha S^{U}$ and $\alpha S^{H}$

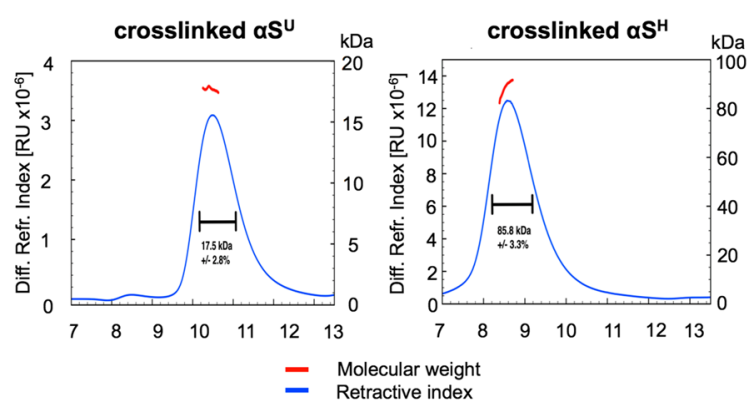

Fig. 1 Cytosolic, multimeric brain-derived $\alpha \mathrm{S}$ is helically folded and exhibits a mass of $86 \mathrm{kDa}$ as demonstrated by circular dichroism spectroscopy (CDS) and multi-angle light scattering (MALS) analyses of purified $\alpha \mathrm{S}^{\mathrm{H}}$ and $\alpha \mathrm{S}^{\mathrm{U}}$ a Elution fractions $1-3$ of a $2 \mathrm{~F} 12$ anti- $\alpha \mathrm{S}$ column incubated with a cross-linked control brain lysate showing the purification of the $\alpha \mathrm{S}$ protein. On the right side, fractions 4-10 after size exclusion chromatography (SEC) are displayed showing the separation of $\alpha \mathrm{S}^{\mathrm{H}}$ and $\alpha \mathrm{S}^{\mathrm{U}}$ for downstream CDS and MALS analysis. b CDS of immunoprecipitated and separated (SEC) $\alpha \mathrm{S}^{\mathrm{H}}$ and $\alpha \mathrm{S}^{\mathrm{U}}$ from human frontal cortex control brain tissue upon cross-linking of brain lysate. The $\alpha \mathrm{S}^{\mathrm{H}}$ from human brain exhibits an $\alpha$-helical secondary structure of $\sim 50 \%$. c CDS of recombinant $\alpha \mathrm{S}$ from $E$. coli. The recombinant $\alpha \mathrm{S}$ is unfolded ( 5\% helical fold, $\sim 95 \%$ unfolded, monomeric). The unfolded structure of recombinant $\alpha \mathrm{S}$ from $E$.

and cingulate cortex ( $p=0.004$, Fig. 2c). PD patients exhibited a significant decrease of $\alpha \mathrm{S}^{\mathrm{H}} / \alpha \mathrm{S}^{\mathrm{U}}$ in the frontal cortex ( $p=0.001$, Fig. 2b). We did not observe significant changes between patients and controls in the entorhinal cortex, a region typically affected by Lewy body (LB) pathology earlier in the disease course than neocortical regions (Online Resource Fig. 13a), the striatum which served as a control region (due to low LB burden, Online Resource Fig. 13b) or the internal control protein DJ1 (Online Resource Fig. 13c-f). Analysis of variance with regard to clinical and neuropathological features (summary Table 1) revealed a significant difference between the reduction of the $\alpha \mathrm{S}^{\mathrm{H}} / \alpha \mathrm{S}^{\mathrm{U}}$ and increased $\alpha \mathrm{S}$ Braak LB staging in the frontal cortex $(p<0.001)$ and cingulate cortex $(p=0.02$, Fig. 2 d, e). A similar difference was observed between increased McKeith staging and reduced $\alpha \mathrm{S}^{\mathrm{H}} / \alpha \mathrm{S}^{\mathrm{U}}$ ratios (frontal cortex $p<0.001$; cingulate cortex $p=0.02$, Online Resource coli remains after cross-linking ( $\sim 5 \%$ helical fold, $95 \%$ unfolded, monomeric). d CDS of purified, native $\alpha \mathrm{S}^{\mathrm{H}}$ from red blood cells (RBC) exhibits a secondary structure of $\sim 45 \%$ helical fold and $\sim 55 \%$ unfolded[4]. Cross-linked $\alpha \mathrm{S}^{\mathrm{H}}$ from HEK cells exhibits an $\alpha$-helical secondary structure of $\sim 48 \%$ helical fold and $52 \%$ unfolded. The cross-linked $\alpha \mathrm{S}^{\mathrm{H}}$ from human brain exhibits an $\alpha$-helical secondary structure of $\sim 50 \%$. e Folded structure of $\alpha \mathrm{S}$ without and with crosslinking demonstrating the difference from human and recombinant origin. f Immunoprecipitated $\alpha \mathrm{S}^{\mathrm{U}}$ from frontal cortex tissue of a control was separated from $\alpha \mathrm{S}^{\mathrm{H}}$ by SEC and analyzed via MALS demonstrating a mass of $\sim 18 \mathrm{kDa}$. Immunoprecipitated $\alpha \mathrm{S}^{\mathrm{H}}$ from frontal cortex tissue of a control was separated from $\alpha \mathrm{S}^{\mathrm{U}}$ by SEC and analyzed via MALS demonstrating a mass of $\sim 86 \mathrm{kDa}$

Fig. 14). A significant difference was also detected between decreased $\alpha \mathrm{S}^{\mathrm{H}} / \alpha \mathrm{S}^{\mathrm{U}}$ ratios and increased Braak neurofibrillary tangle (NFT) staging in the entorhinal cortex $(p=0.04$, Online Resource Fig. 14). All other clinical features such as gender, age or post-mortem interval (Table 1) were not associated with the reduction of $\alpha \mathrm{S}^{\mathrm{H}} / \alpha \mathrm{S}^{\mathrm{U}}$ (data not shown). Hence, these data indicate a region-specific destabilization of physiological $\alpha \mathrm{S}$ in brain regions affected by LB pathology.

\section{$a S^{H}$ exhibits "prion-like" aggregation-resistant properties}

Given the apparent disease and region specificity of the $\alpha \mathrm{S}^{\mathrm{H}}$ destabilization, and the discussed "prion-like" aggregation transmission of pathological $\alpha \mathrm{S}$ in a highly region-specific manner, we analyzed whether the $\alpha \mathrm{S}^{\mathrm{H}}$ form of $\alpha \mathrm{S}$, being 
Table 1 Overview of samples and processed brain tissue for Fig. 2

\begin{tabular}{|c|c|c|c|c|c|c|c|c|c|c|c|c|}
\hline Case \# & $\begin{array}{l}\text { Age at } \\
\text { death [years] }\end{array}$ & Gender & $\begin{array}{l}\text { Disease } \\
\text { duration } \\
\text { [years] }\end{array}$ & $\begin{array}{l}\text { PMI } \\
\text { [hours] }\end{array}$ & McKeith & Braak LB & Braak NFT & CERAD & $\mathrm{FC}$ & $\mathrm{CC}$ & $\mathrm{EC}$ & Str. \\
\hline Control 1 & 77 & Male & & 83 & & & 2 & Absent & & $\mathrm{x}$ & & \\
\hline Control 2 & 74 & Female & & 53 & & & 3 & Absent & & $\mathrm{x}$ & & \\
\hline Control 3 & 95 & Female & & 39 & & & 4 & Moderate & $\mathrm{x}$ & & & $\mathrm{x}$ \\
\hline Control 4 & 99 & Female & & 32 & & & 4 & Frequent & $\mathrm{x}$ & & & $\mathrm{x}$ \\
\hline Control 5 & 87 & Male & & 39 & & & 1 & Absent & $\mathrm{x}$ & & & $\mathrm{x}$ \\
\hline Control 6 & 57 & Female & & 13 & & & & & $\mathrm{x}$ & & & \\
\hline Control 7 & 86 & Male & & 10 & & & & & $\mathrm{x}$ & & & \\
\hline Control 8 & 92 & Male & & 24 & & & 2 & Absent & $\mathrm{x}$ & & & $\mathrm{x}$ \\
\hline Control 9 & 92 & Male & & 23 & & & 2 & Sparse & $\mathrm{x}$ & & & $\mathrm{x}$ \\
\hline Control 10 & 54 & Male & & 6 & & & 0 & Absent & $\mathrm{x}$ & & & $\mathrm{x}$ \\
\hline Control 11 & 60 & Male & & & & & & & $\mathrm{x}$ & & & \\
\hline Control 12 & 75 & Female & & & & & 4 & & $\mathrm{x}$ & & & \\
\hline Control 13 & 81 & Female & & & & & 2 & & $\mathrm{x}$ & & & \\
\hline Control 14 & 75 & Female & & & & & 3 & & $\mathrm{x}$ & & & \\
\hline Control 15 & 81 & Male & & & & & 3 & & $\mathrm{x}$ & & & \\
\hline Control 16 & 78 & Male & & & & & 2 & & $\mathrm{x}$ & & & \\
\hline Control 17 & 79 & Female & & & & & 2 & & $\mathrm{x}$ & & & \\
\hline Control 18 & 70 & Male & & & & & 2 & & $\mathrm{x}$ & & & \\
\hline Control 19 & 63 & Male & & & & & 3 & & $\mathrm{x}$ & & & \\
\hline Control 20 & 87 & Female & & & & & 3 & & $\mathrm{x}$ & & & \\
\hline Control 21 & 88 & Female & & & & & 5 & & $\mathrm{x}$ & & & \\
\hline Control 22 & 90 & Male & & 46 & & & 4 & Moderate & & & $\mathrm{x}$ & \\
\hline Control 23 & 76 & Male & & 79 & & & 2 & Absent & & $\mathrm{x}$ & $\mathrm{x}$ & \\
\hline Control 24 & 84 & Female & & 54 & & & 2 & Absent & & $\mathrm{x}$ & $\mathrm{x}$ & \\
\hline Control 25 & 83 & Female & & 99 & & & 2 & Sparse & & $\mathrm{x}$ & $\mathrm{x}$ & \\
\hline Control 26 & 89 & Male & & 156 & & & 3 & Sparse & & $\mathrm{x}$ & $\mathrm{x}$ & \\
\hline Control 27 & 82 & Female & & 91 & & & 2 & Sparse & & $\mathrm{x}$ & $\mathrm{x}$ & \\
\hline Control 28 & 84 & Male & & 79 & & & 1 & & & & $\mathrm{x}$ & \\
\hline DLB 1 & 77 & Male & 2.5 & 29 & Neocortical & 6 & 2 & Moderate & & $\mathrm{x}$ & & \\
\hline DLB 2 & 71 & Male & 5 & 22 & Neocortical & 6 & 3 & Moderate & $\mathrm{x}$ & $\mathrm{x}$ & $\mathrm{x}$ & \\
\hline DLB 3 & 72 & Male & 8 & 89 & Neocortical & 6 & 3 & Absent & $\mathrm{x}$ & $\mathrm{x}$ & $\mathrm{x}$ & \\
\hline DLB 4 & 84 & Male & 10 & 72 & Neocortical & 6 & 2 & Absent & $\mathrm{x}$ & $\mathrm{x}$ & $\mathrm{x}$ & \\
\hline DLB 5 & 73 & Female & 6 & 73 & Neocortical & 6 & 3 & Absent & $\mathrm{x}$ & $\mathrm{x}$ & $\mathrm{x}$ & \\
\hline DLB 6 & 76 & Male & 8 & 13 & Neocortical & 6 & 2 & Sparse & $\mathrm{x}$ & & & \\
\hline DLB 7 & 81 & Male & 5 & 26 & Neocortical & 6 & 3 & Moderate & $\mathrm{x}$ & $\mathrm{x}$ & $\mathrm{x}$ & \\
\hline DLB 8 & 81 & Male & 3 & 81 & Neocortical & 6 & 3 & Moderate & $\mathrm{x}$ & $\mathrm{x}$ & $\mathrm{x}$ & \\
\hline DLB 9 & 60 & Male & 8 & 24 & Neocortical & 6 & 1 & Moderate & $\mathrm{x}$ & & & $\mathrm{x}$ \\
\hline DLB 10 & 67 & Male & 7 & 40 & Neocortical & 6 & 3 & Moderate & $\mathrm{x}$ & & & $\mathrm{x}$ \\
\hline DLB 11 & 79 & Female & & 12 & Neocortical & 6 & 4 & Sparse & $\mathrm{x}$ & & & \\
\hline DLB 12 & 83 & Male & 8 & 54 & & & & & $\mathrm{x}$ & & & $\mathrm{x}$ \\
\hline DLB 13 & 63 & Female & 10 & & & & 4 & & $\mathrm{x}$ & & & $\mathrm{x}$ \\
\hline DLB 14 & 81 & Female & & & Neocortical & 6 & 3 & & $\mathrm{x}$ & & & \\
\hline DLB 15 & 67 & Female & & & Neocortical & 6 & 4 & & $\mathrm{x}$ & & & \\
\hline PD 1 & 42 & Male & 4 & 42 & Neocortical & 6 & 4 & & & $\mathrm{x}$ & $\mathrm{x}$ & \\
\hline PD 2 & 78 & Male & 3 & 24 & Neocortical & 6 & 0 & Absent & & $\mathrm{x}$ & $\mathrm{x}$ & \\
\hline PD 3 & 83 & Female & 8 & 99 & Neocortical & 6 & 3 & & & $\mathrm{x}$ & $\mathrm{x}$ & \\
\hline PD 4 & 76 & Male & 6 & 85 & Neocortical & 6 & 6 & & & $\mathrm{x}$ & $\mathrm{x}$ & \\
\hline PD 5 & 76 & Male & 7 & 49 & Neocortical & 6 & 1 & Sparse & & $\mathrm{x}$ & $\mathrm{x}$ & \\
\hline
\end{tabular}


Table 1 (continued)

\begin{tabular}{|c|c|c|c|c|c|c|c|c|c|c|c|c|}
\hline Case \# & $\begin{array}{l}\text { Age at } \\
\text { death [years] }\end{array}$ & Gender & $\begin{array}{l}\text { Disease } \\
\text { duration } \\
\text { [years] }\end{array}$ & $\begin{array}{l}\text { PMI } \\
\text { [hours] }\end{array}$ & McKeith & Braak LB & Braak NFT & CERAD & $\mathrm{FC}$ & $\mathrm{CC}$ & $\mathrm{EC}$ & Str. \\
\hline PD 6 & 82 & Male & 11 & 7 & Neocortical & 6 & 2 & Absent & & $\mathrm{x}$ & $\mathrm{x}$ & $\mathrm{x}$ \\
\hline PD 7 & 81 & Male & 13 & 46 & Neocortical & 6 & 2 & Absent & $\mathrm{x}$ & & & $\mathrm{x}$ \\
\hline PD 8 & 74 & Male & 16 & 55 & Neocortical & 6 & 2 & Absent & $\mathrm{x}$ & & & \\
\hline PD 9 & 79 & Female & 15 & 65 & Neocortical & 6 & 2 & Mild & $\mathrm{x}$ & & & $\mathrm{x}$ \\
\hline PD 10 & 79 & Female & 14 & 27 & Neocortical & 6 & 4 & Absent & $\mathrm{x}$ & & & $\mathrm{x}$ \\
\hline PD 11 & 75 & Male & 22 & 11 & Neocortical & 6 & 2 & Absent & $\mathrm{x}$ & & & $\mathrm{x}$ \\
\hline PD 12 & 76 & Male & 10 & 29 & Neocortical & 6 & 2 & Absent & $\mathrm{x}$ & & & \\
\hline PD 13 & 87 & Male & & 38 & Limbic & 3 & 1 & Sparse & & & & $\mathrm{x}$ \\
\hline PD 14 & 73 & Male & & 24 & Limbic & 4 & & & $\mathrm{x}$ & & & \\
\hline PD 15 & 87 & Female & & 6 & Limbic & 4 & 2 & Sparse & $\mathrm{x}$ & & & \\
\hline
\end{tabular}

$D L B$ dementia with Lewy bodies, PD Parkinson's disease, PMI post-mortem interval, $L B$ Lewy bodies, NFT neurofibrillary tangles, $C E R A D$ Consortium to Establish a Registry for Alzheimer's Disease, $F C$ frontal cortex, $C C$ cingulate cortex, $E C$ entorhinal cortex, Str. striatum

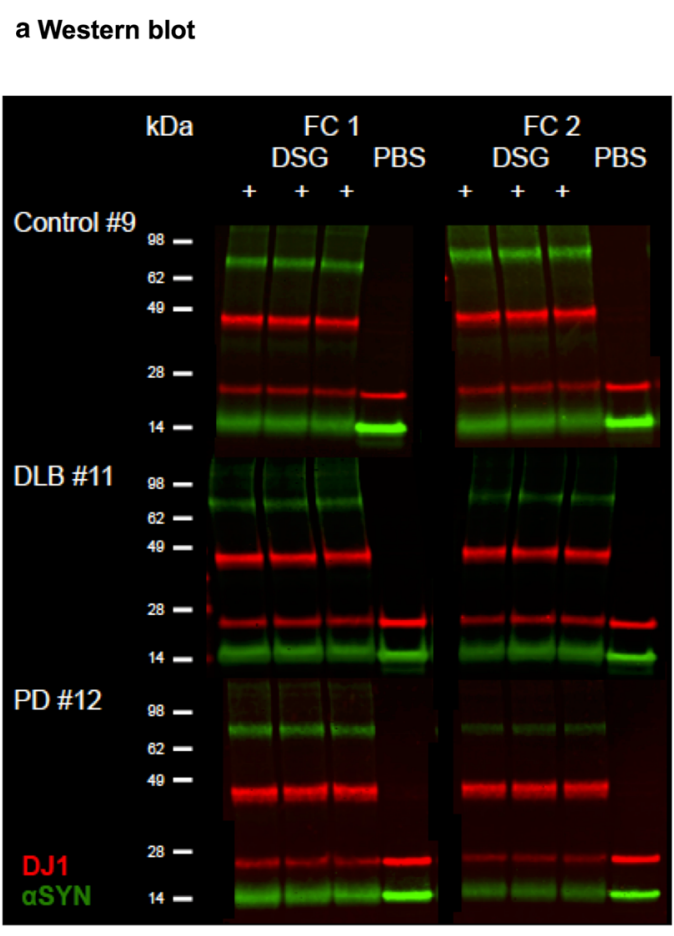

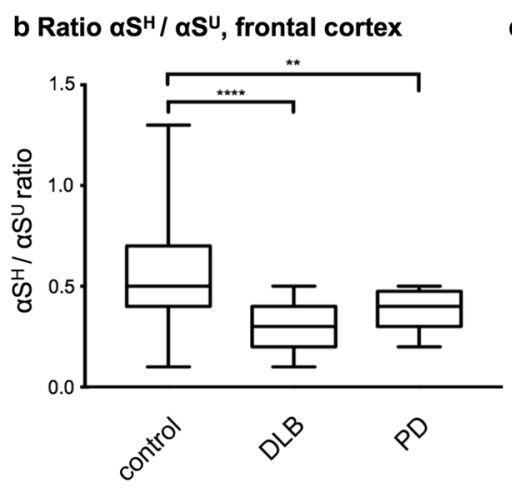

d Ratio $\alpha \mathbf{S}^{\mathrm{H}} / \alpha \mathbf{S}^{U}$ in comparison to the Braak staging, frontal cortex

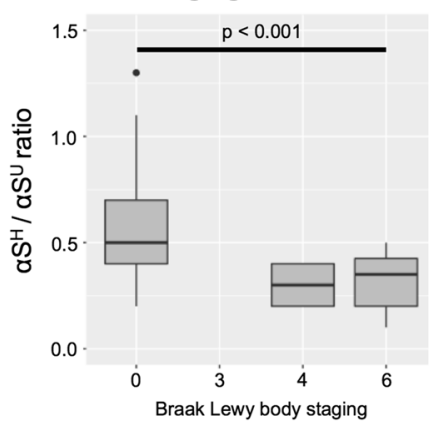

c Ratio $\alpha S^{H} / \alpha S^{U}$, cingulate cortex

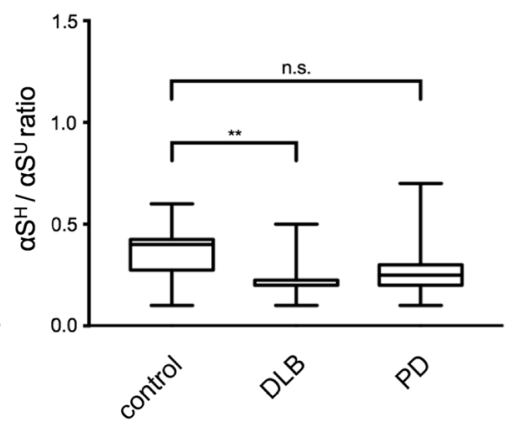

e Ratio $\alpha \mathrm{S}^{\mathrm{H}} / \alpha \mathrm{S}^{\mathrm{U}}$ in comparison to the Braak staging, cingulate cortex

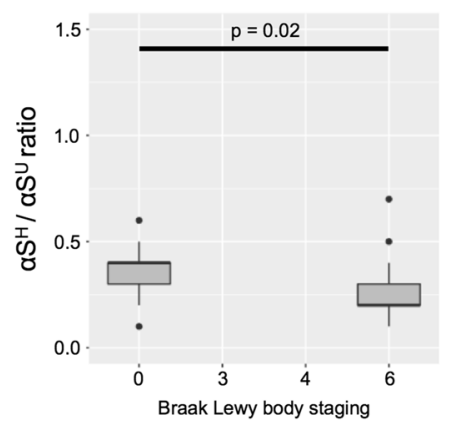

Fig. 2 Equilibriums of cytosolic helically folded and unfolded physiological $\alpha \mathrm{S}$ is disturbed in PD and DLB patients. a Representative Western blot of $\alpha \mathrm{S}^{\mathrm{H}}$ and $\alpha \mathrm{S}^{\mathrm{U}}$ in controls, DLB and PD patients. Each piece of brain was analyzed in duplicates (frontal cortex FC1 and FC2). The cross-linking reaction was performed in technical triplicates alongside one non-cross-linked (PBS) sample. The Western blot demonstrates reduced $\alpha \mathrm{S}^{\mathrm{H}}$ to $\alpha \mathrm{S}^{\mathrm{U}}$ ratios in DLB and PD patients compared to the control. DSG "+"=cross-linked sample. DSG “-"= non-cross-linked sample. Green $=\alpha$ S, red=DJ1. b Sig- nificant reduction of $\alpha \mathrm{S}^{\mathrm{H}} / \alpha \mathrm{S}^{\mathrm{U}}$ ratio in the frontal cortex comparing controls $(n=19)$ with DLB $(n=14)$ and PD $(n=8)$ patients. c Significant reduction of $\alpha \mathrm{S}^{\mathrm{H}} / \alpha \mathrm{S}^{\mathrm{U}}$ ratio in the cingulate cortex comparing controls $(n=7)$ to DLB $(n=7)$ patients. No significant alteration of the $\alpha \mathrm{S}^{\mathrm{H}} / \alpha \mathrm{S}^{\mathrm{U}}$ equilibriums in the cingulate cortex comparing controls $(n=7)$ and PD $(n=6)$ patients. d Significant difference of decreased $\alpha \mathrm{S}^{\mathrm{H}} / \alpha \mathrm{S}^{\mathrm{U}}$ ratios and increased Braak LB staging of the frontal cortex $(p<0.001)$. e Significant difference of decreased $\alpha \mathrm{S}^{\mathrm{H}} / \alpha \mathrm{S}^{\mathrm{U}}$ ratios and increased Braak LB staging of the cingulate cortex $(p=0.02)$ 
a ThT-aggregation assay of recombinant $\alpha \mathbf{S}^{U}$ and $\mathbf{R B C}$-derived $\alpha \mathbf{S}^{\mathrm{H}}$

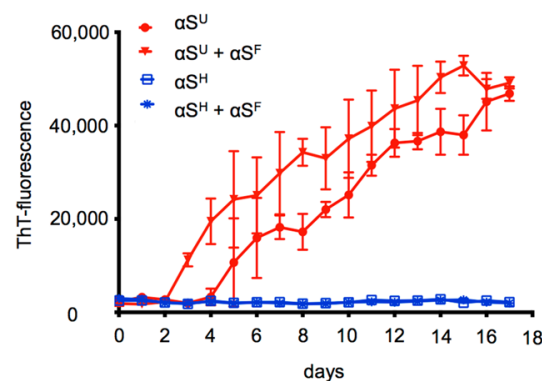

d Correlation of $\alpha \mathrm{S}^{\mathrm{H}} / \alpha \mathrm{S}^{\mathrm{U}}$ ratio and insoluble aS in M17D fPD

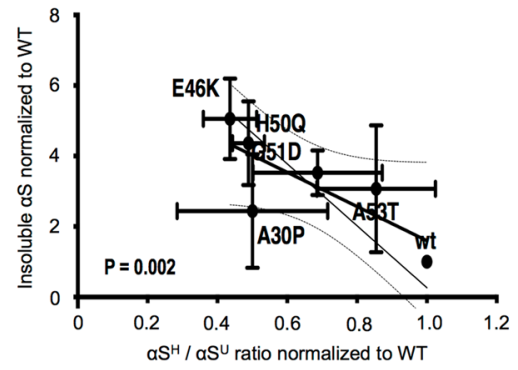

b Amounts of insouble aS in M17D fPD
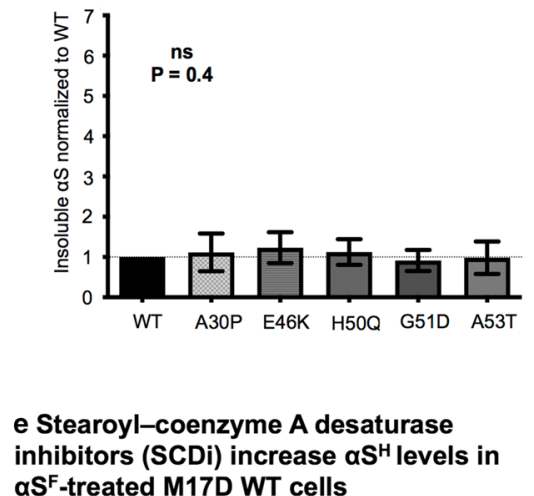
aSF-treated M17D WT cells

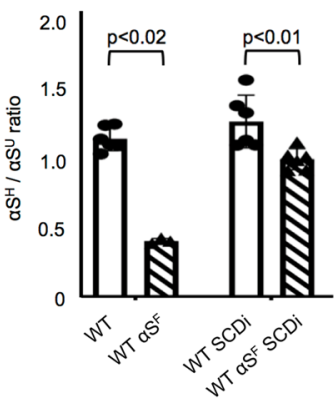

C Amounts of insouble $\alpha S$ in $\alpha S^{F-s e e d e d ~}$ M17D fPD

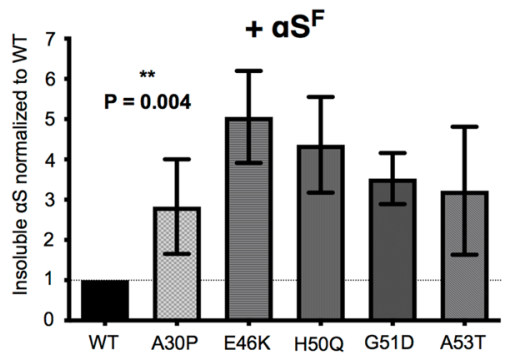

desaturase inhibitors (SCDi) on inclusion formation in M17D WT cells

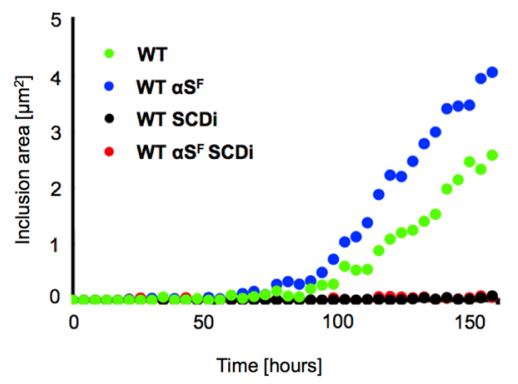

Fig. $3 \alpha \mathrm{S}^{\mathrm{H}}$ is resistant to spontaneous or "prion-like" induced aggregation compared to $\alpha \mathrm{S}^{\mathrm{U}}$ and modulates "prion-like" aggregation transmission in cellular models of disease. a Thioflavin T-fluorescence assay monitoring the aggregation of recombinant $\alpha \mathrm{S}^{\mathrm{U}}$ and purified $\alpha \mathrm{S}^{\mathrm{H}}$ from erythrocytes. In samples that were seeded, $10 \mathrm{nM}$ recombinant fibrillar $\alpha S\left(\alpha S^{\mathrm{F}}\right)$ (i.e., 1:1000) was added. The $\alpha S^{\mathrm{H}}$ multimer demonstrated resistance to both spontaneous and seeded aggregation. b M17D cells transfected with wt $\alpha \mathrm{S}$, or the fPD related mutations A30P, E46K, H50Q, G51D and A53T. Cells with fPD mutations display equal amounts of insoluble $\alpha$ S. Cells were analyzed in biological triplicates. $\mathbf{c} \alpha \mathrm{S}^{\mathrm{F}}$-seeded M17D cells display increased levels of insoluble $\alpha \mathrm{S}$. Cells were analyzed in biological triplicates. d $\alpha \mathrm{S}^{\mathrm{H}}$ destabilization correlates significantly (Deeming regression analysis) with susceptibility towards $\alpha \mathrm{S}$ aggregation as measured by insoluble $\alpha \mathrm{S}$ in M17D after 2 days of seeding $(p=0.002)$. Cells were analyzed in biological triplicates. e SCDi treated and $\alpha S^{F}$-seeded M17D cells exhibit increased $\alpha \mathrm{S}^{\mathrm{H}} / \alpha \mathrm{S}^{\mathrm{U}}$ ratios compared to $\alpha \mathrm{S}^{\mathrm{F}}$-seeded

resistant to spontaneous aggregation, can also protect against the self-templating "prion-like" aggregation mediated by $\alpha S^{\mathrm{F}}$. Therefore, we performed a thioflavin T-based aggregation assay on purified $\alpha \mathrm{S}$ and separated $\alpha \mathrm{S}^{\mathrm{H}}$ multimers and $\alpha \mathrm{S}^{\mathrm{U}}$ monomers. As the cross-linker interfered with ThT assays (Online Resource Fig. 15a), we prepared native, noncross-linked $\alpha \mathrm{S}^{\mathrm{H}}$ from human blood and $\alpha \mathrm{S}^{\mathrm{U}}$ from $E$. coli, given the difficulty of native $\alpha \mathrm{S}$ purification from brain [38], and assessed its susceptibility toward "prion-like" aggregation. Our ThT-aggregation assay showed that $\alpha \mathrm{S}^{\mathrm{H}}$-in contrast to monomeric $\alpha \mathrm{S}^{\mathrm{U}}$ - did not form ThT-bound fibrils (Fig. 3a). The addition of recombinant "prion-like" $\alpha S^{\mathrm{F}}$ did stimulate the aggregation in the $\alpha \mathrm{S}^{\mathrm{U}}$ monomer, but
M17D wt cells. Cells were seeded at a density of $0.1 * 10^{\circ} 6$ cells/ $\mathrm{ml}$ in a 12 well plate Twenty-four hours after seeding, a third fraction of the cells were treated with $10 \mu \mathrm{M}$ SCDi or DMSO. Twentyfour hours after the treatment, some cells were seeded with $0.5 \mu \mathrm{g} /$ $\mathrm{ml} \alpha \mathrm{S}^{\mathrm{F}}$. Another $48 \mathrm{~h}$ and $96 \mathrm{~h}$ after seeding, SCDi or DMSO was added again. The cross-linking experiments were carried out in 6 independent experiments. f SCDi prevent the formation of pathological $\alpha \mathrm{S}$ inclusions even in the presence of $\alpha \mathrm{S}^{\mathrm{F}}$. Cells were seeded at a density of $0.1 * 10^{\circ} 6$ cells $/ \mathrm{ml}$ in a 12 well plate. Twenty-four hours after seeding, a third fraction of the cells were treated with $10 \mu \mathrm{M}$ SCDi or DMSO. Twenty-four hours after the treatment, some cells were seeded with $0.5 \mu \mathrm{g} / \mathrm{ml} \alpha \mathrm{S}^{\mathrm{F}}$. Another $48 \mathrm{~h}$ and $96 \mathrm{~h}$ after seeding, SCDi or DMSO was added again. Aggregation was monitored until a decrease in viability in the seeded cells precluded comparison with the control group $(\sim 150 \mathrm{~h})$. The experiments were carried out in biological duplicates. $R B C$ red blood cells, $f P D$ familial PD, $W T$ wild type, $S C D i$ stearoyl-coenzyme A desaturase inhibitor

not in the $\alpha \mathrm{S}^{\mathrm{H}}$ multimer, hence indicating that the cytosolic helical structure found in human brain is not susceptible to putative "prion-like" aggregation transmission of amyloid protein species (Fig. 3a). Furthermore, addition of $\alpha S^{F}$ did not lead to destabilization of purified $\alpha \mathrm{S}^{\mathrm{H}}$. In addition, we analyzed M17D cells with high $\alpha \mathrm{S}^{\mathrm{H}} / \alpha \mathrm{S}^{\mathrm{U}}$ ratios and found that the addition of $\alpha S^{\mathrm{F}}$ to wt cells did not result in a significant decrease of $\alpha \mathrm{S}^{\mathrm{H}} / \alpha \mathrm{S}^{\mathrm{U}}$ ratios (Online Resource Fig. 15b), indicating that while stabilization of $\alpha \mathrm{S}^{\mathrm{H}}$ protects from detrimental effects, $\alpha \mathrm{S}^{\mathrm{F}}$ (amyloid itself) is not causal for destabilization of $\alpha \mathrm{S}^{\mathrm{H}}$. Taken together, these data suggest that a decrease in $\alpha \mathrm{S}^{\mathrm{H}} / \alpha \mathrm{S}^{\mathrm{U}}$ ratios potentially leads to a raised susceptibility in neurons for "prion-like" transmission of $\alpha \mathrm{S}$ 
amyloid. To test this, we stimulated "prion-like" aggregation in human neuronal cells (M17D) expressing $\alpha S$ constructs with varying $\alpha \mathrm{S}^{\mathrm{H}} / \alpha \mathrm{S}^{\mathrm{U}}$ ratios (wt or previously described $\alpha \mathrm{S}^{\mathrm{H}}$ destabilizing fPD mutations) by addition of preformed $\alpha S^{\mathrm{F}}$ to the cell media. We then assessed the amount of (Triton$\mathrm{X}$ ) insoluble $\alpha \mathrm{S}$ found in the cell pellets by $\alpha \mathrm{S}$ ELISA after 2 days of seeding. While no differences in forming insoluble $\alpha \mathrm{S}$ were found in cells expressing fPD mutations without treatment (Fig. 3b), the addition of $\alpha S^{\mathrm{F}}$ to the growth medium led to a significant increase of aggregated $\alpha \mathrm{S}$ in the neuronal cell line across all fPD mutations, indicating an increased "prion-like" aggregation susceptibility compared to wild type (wt, Fig. 3c). This directly indicates that all fPD mutations lead to greater susceptibility toward "prion-like" aggregation in neuronal cells, while their effect on spontaneous aggregation is comparatively small. In accordance with previous published data [14], we detected a decrease of $\alpha \mathrm{S}^{\mathrm{H}}$ / $\alpha \mathrm{S}^{\mathrm{U}}$ ratio in the lysate of M17D cells expressing different familial PD SNCA mutations (A30P, G51D, A53T, E46K and $\mathrm{H} 50 \mathrm{Q}$, respectively) compared to wt (Fig. 3d). The decrease of $\alpha \mathrm{S}^{\mathrm{H}} / \alpha \mathrm{S}^{\mathrm{U}}$ ratios caused by these mutations correlated significantly with the susceptibility toward "prionlike" aggregation as measured by insoluble $\alpha \mathrm{S}$ in $\alpha \mathrm{S}^{\mathrm{F}}$-seeded M17D cells ( $p=0.002$, Fig. $3 \mathrm{~d})$. In contrast, M17D cells with higher $\alpha \mathrm{S}^{\mathrm{H}} / \alpha \mathrm{S}^{\mathrm{U}}$ ratios exhibited decreased seeding and aggregation capabilities, indicating that increased $\alpha \mathrm{S}^{\mathrm{H}}$ stabilization in neuronal cells is protective against "prion-like" propagation (Fig. 3d). To establish a causal link between $\alpha S^{\mathrm{H}}$ stability and "prion-like" aggregation resistance, we next performed rescue experiments with a stearoyl-coenzyme A desaturase inhibitors (SCDi), a known pharmacological stabilizer of $\alpha \mathrm{S}$ multimers [19, 30, 45] leading to an increase in the relative amount of protective $\alpha \mathrm{S}^{\mathrm{H}}$ in our M17D cells (Fig. 3e). We then seeded M17D cells expressing YFP-tagged wt $\alpha \mathrm{S}$ and followed the $\alpha \mathrm{S}$ inclusion formation under $\alpha S^{\mathrm{F}}$ addition via automated confocal microscopy (IncuCuyte). Here, the multimer-stabilizer SCDi prevents the formation of pathological $\alpha \mathrm{S}$ inclusions even in the presence of $\alpha S^{\mathrm{F}}$ (Fig. 3f), indicating a rescue of "prion-like" susceptibility through the stabilization of physiologically $\alpha \mathrm{S}^{\mathrm{H}}$. This protective stabilization even extended to the spontaneous aggregation seen in wt $\alpha \mathrm{S}$ expressing neuronal cells without $\alpha \mathrm{S}^{\mathrm{F}}$ addition (Fig. 3f).

\section{The disequilibrium of $a S^{H}$ and $a S^{U}$ is brain region specific and associated with dementia in PD and DLB patients}

To validate the association between the region-specific distribution and the proposed "prion-like" aggregation transmission theory of $\alpha \mathrm{S}$, we carried out an analysis of nine brain regions from 10 controls, 6 DLB and 13 sporadic PD patients (Table 2). All brain regions for each individual were analyzed in biological and technical duplicates ( $n=1044$ single samples). Compared to the analysis of the four brain regions, which used PD patients mostly at their extremes (Braak 6), we were able to include selected PD patients with Braak stages 4 and 5 and additional clinical information such as the cognitive status or Thal phases (Table 2).

The brain regions selected for the analysis reflect the typical temporal development of LB pathology across the limbic and neocortical regions, with early affected areas [amygdala, cortex of parahippocampal gyrus (PHG) and anterior cingulate cortex (ACC)] in Braak stage 4, later affected areas [cortex of insula, middle temporal (MTG) and anterior middle frontal gyri (AMFG)] corresponding to Braak stage 5 and first-order sensory association area [inferior parietal lobule (IPL)] in Braak stage 6. Also, the cortex of the transverse temporal gyrus (Heschl's gyrus) and occipital cortex (OC, not collected from primary visual cortex), which are regions typically spared from LB pathology or affected late in disease course, were included in the analysis (Fig. 4). We investigated the changes across all nine brain regions and used the slope or trendline calculated for the regions for further comparisons. Interestingly, in this extended brain region analysis, PD patients had significantly higher slopes across the nine brain regions compared to controls (Fig. 4a, $p=0.006$ ). The slopes dropped in PD patients with dementia and further declined in DLB patients which were all reported to be demented compared to PD patients without dementia (Fig. 4, $p=0.003$ ). It became obvious that in controls, $\alpha \mathrm{S}^{\mathrm{H}} / \alpha \mathrm{S}^{\mathrm{U}}$ ratios in the later affected brain areas, according to the classical Braak staging, were not higher compared to PD samples per se (Fig. 4b, d-f). The important changes worked out in the analysis of the nine brain regions is as follows: five of six DLB patients exhibited decreased slopes, meaning lower $\alpha \mathrm{S}^{\mathrm{H}} / \alpha \mathrm{S}^{\mathrm{U}}$ ratios, in the later affected brain regions according to the classical Braak staging (Fig. 4c). PD patients Braak 4, Braak 5 and PD patients Braak 6 without dementia had increasing slopes, thus higher $\alpha \mathrm{S}^{\mathrm{H}} /$ $\alpha \mathrm{S}^{\mathrm{U}}$ ratios, especially in the IPL, Heschl's gyrus and OC (Fig. 4d-f). Interestingly, some PD Braak 6 patients, those with dementia, also showed decreased slopes across the nine brain regions similar to DLB patients resulting in low $\alpha \mathrm{S}^{\mathrm{H}}$ / $\alpha S^{U}$ ratios in the IPL, Heschl's gyrus and OC (Fig. 4f). We performed a linear regression analysis with all available clinical variables (Table 2) and could support those findings by identifying dementia as the only significant predictor of the outcome variable, the $\alpha \mathrm{S}^{\mathrm{H}} / \alpha \mathrm{S}^{\mathrm{U}}$ ratios $(p=0.03$, $R^{2}=0.3$ ). Overall, in PD patients Braak 4 and 5 with and without dementia, the slopes across the nine brain regions remained positive with higher $\alpha \mathrm{S}^{\mathrm{H}} / \alpha \mathrm{S}^{\mathrm{U}}$ ratios in the later affected brain regions (Fig. 4d-e). In PD and DLB patients Braak 6, the slopes clearly separated those patients with (decreased slopes) and without dementia (increased slopes, Fig. $4 \mathrm{c}, \mathrm{f})$. Thus, the disequilibrium of $\alpha \mathrm{S}^{\mathrm{H}} / \alpha \mathrm{S}^{\mathrm{U}}$ ratios in 
Table 2 Information on samples, cross-linking aggregation transmission analysis ( 9 brain regions)

\begin{tabular}{|c|c|c|c|c|c|c|c|c|c|c|}
\hline Case \# & $\begin{array}{l}\text { PMI } \\
\text { [hours] }\end{array}$ & $\begin{array}{l}\text { Age at } \\
\text { death } \\
\text { [years] }\end{array}$ & Gender & $\begin{array}{l}\text { Disease dura- } \\
\text { tion [years] }\end{array}$ & Dementia & Thal & Braak NFT & CERAD & Braak LB & McKeith \\
\hline Control 1 & 79 & 84 & Male & & No & 0 & 0 & Absent & 0 & None \\
\hline Control 2 & 105 & 79 & Male & & No & 0 & 2 & Absent & 0 & None \\
\hline Control 3 & 120 & 86 & Female & & No & 0 & 2 & Absent & 0 & None \\
\hline Control 4 & 60 & 96 & Female & & No & 2 & 2 & Absent & 0 & None \\
\hline Control 5 & 47 & 89 & & & No & 3 & 2 & Mild & 0 & None \\
\hline Control 6 & 61 & 101 & Male & & No & 0 & 1 & Absent & 0 & None \\
\hline Control 7 & 79 & 76 & Male & & No & 1 & 2 & Absent & 0 & None \\
\hline Control 8 & 3 & 71 & Female & & No & 2 & 3 & Absent & 0 & None \\
\hline Control 9 & 2 & 84 & Female & & No & 3 & 2 & Mild & 0 & None \\
\hline Control 10 & 2 & 87 & Male & & No & 2 & 2 & Mild & 0 & None \\
\hline DLB 1 & 45 & 63 & Female & 10 & Yes & & 6 & Frequent & 6 & Diffuse neocortical \\
\hline DLB 2 & 70 & 68 & Male & 13 & Yes & 5 & 6 & Frequent & 6 & Diffuse neocortical \\
\hline DLB 3 & 63 & 59 & Female & 10 & Yes & 5 & 3 & Moderate & 6 & Diffuse neocortical \\
\hline DLB 4 & 24 & 60 & Male & 8 & Yes & 1 & 1 & Moderate & 6 & Diffuse neocortical \\
\hline DLB 5 & 56 & 75 & Male & 16 & Yes & 1 & 2 & Sparse & 6 & Diffuse neocortical \\
\hline DLB 6 & 55 & 79 & Male & 10 & Yes & 4 & 2 & Sparse & 6 & Diffuse neocortical \\
\hline PD 1 & 114 & 82 & Male & 34 & No & 1 & 1 & Absent & 4 & Brainstem \\
\hline PD 2 & 98 & 77 & Male & 8 & Yes & 1 & 2 & Absent & 4 & Limbic \\
\hline PD 3 & 16 & 74 & Male & 13 & Yes & 1 & 0 & Absent & 4 & Brainstem \\
\hline PD 4 & 99 & 80 & Male & 6 & No & 0 & 2 & Absent & 5 & Limbic \\
\hline PD 5 & 89 & 86 & Female & 27 & No & 0 & 2 & Absent & 5 & Limbic \\
\hline PD 6 & 85 & 78 & Female & 11 & No & 1 & 1 & Absent & 5 & Limbic \\
\hline PD 7 & 35 & 92 & Male & 13 & No & 0 & 2 & Absent & 6 & Diffuse neocortical \\
\hline PD 8 & 24 & 63 & Male & 21 & & 0 & 1 & Absent & 6 & Diffuse neocortical \\
\hline PD 9 & 87 & 76 & Female & 15 & No & 0 & 1 & Absent & 6 & Diffuse neocortical \\
\hline PD 10 & 105 & 85 & Female & 25 & Yes & 0 & 2 & Absent & 6 & Diffuse neocortical \\
\hline PD 11 & 100 & 72 & Male & 28 & Yes & 1 & 2 & Absent & 6 & Diffuse neocortical \\
\hline PD 12 & 41 & 70 & Female & 39 & Yes & 0 & 2 & Absent & 6 & Diffuse neocortical \\
\hline PD 13 & 25 & 70 & Female & 27 & No & 1 & 1 & Absent & 6 & Diffuse neocortical \\
\hline
\end{tabular}

$P D$ Parkinson's disease, $D L B$ dementia with Lewy bodies, $C E R A D$ Consortium to Establish a Registry for Alzheimer's Disease, $P M I$ post-mortem interval, $L B$ Lewy bodies, NFT neurofibrillary tangles

the cortical regions across all nine brain regions seems to be critical for PD and DLB patients. Thus, we assume that the individual equilibrium in PD and DLB patients and especially the cortical $\alpha \mathrm{S}^{\mathrm{H}} / \alpha \mathrm{S}^{\mathrm{U}}$ ratios are disturbed during the disease. These findings were further supported by applying a semiquantitative LB score across the nine brain regions showing that with increasing Braak stages in PD patients and Braak 6 DLB patients, the LB score increases in the later affected brain regions, especially insula, IPL, Heschl's gyrus and $\mathrm{OC}$ (Fig. 4g). The increased means of the semiquantitative LB score comparing controls, PD and DLB patients was significantly different from the decreasing mean $\alpha \mathrm{S}^{\mathrm{H}} / \alpha \mathrm{S}^{\mathrm{U}}$ slopes compared across all groups ( $p=0.02$, Fig. 4h). Thus, when the disease progresses and LB scores raise, $\alpha \mathrm{S}^{\mathrm{H}} / \alpha \mathrm{S}^{\mathrm{U}}$ ratios decline, especially in demented individuals. These findings further support the region-specific distribution and the proposed "prion-like" aggregation transmission theory of $\alpha \mathrm{S}$.

In summary, when the equilibrium of $\alpha \mathrm{S}^{\mathrm{H}} / \alpha \mathrm{S}^{\mathrm{U}}$ shifts toward the aggregation-prone $\alpha \mathrm{S}^{\mathrm{U}}$ in PD and DLB patients, our data demonstrate that the likelihood of fibril formation, and subsequently LB inclusions, increases. Our current findings provide a novel mechanism, in which the equilibrium of physiological aggregation-resistant $\alpha \mathrm{S}$ multimers and physiological, aggregation-prone $\alpha \mathrm{S}$ monomers is disturbed in sporadic PD and DLB patients, governing the regions affected in the brain and clinical outcome (Fig. 5). Local and individual changes might modify the differential caudo-rostral progression in these synucleinopathies, if the pathology originates in the brain stem as currently described (Fig. 5). The data imply that brain stem pathology would either arrive in neuronal tissue with 
a Comparison of $\alpha S^{H} / \alpha S^{U}$ ratios (slopes) across 9 different brain regions

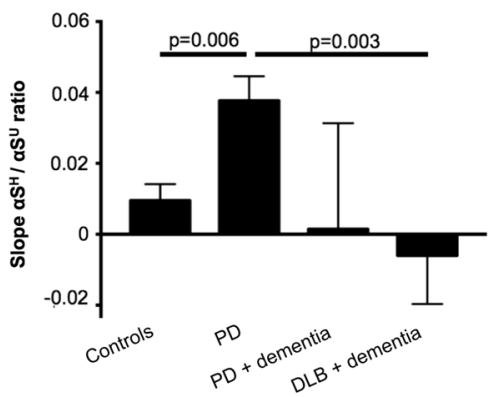

d PD Braak 4 comparison of $\alpha S^{H} / \alpha S^{U}$ ratios across different brain regions

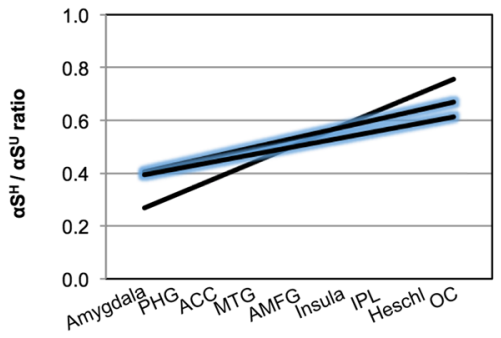

g Comparison of semiquantitative Lewy body scores across different brain regions
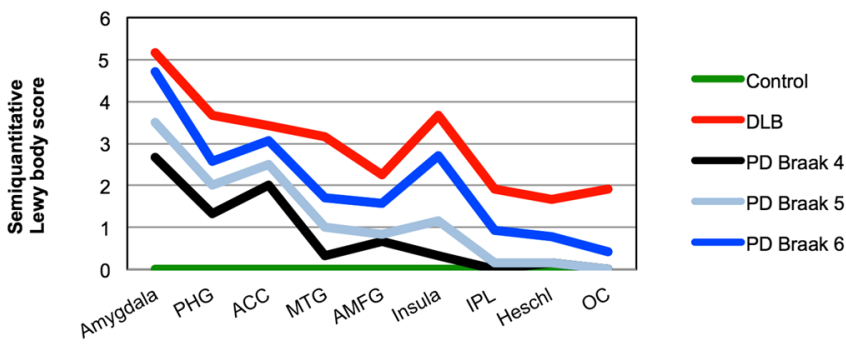

Fig. $4 \alpha \mathrm{S}^{\mathrm{H}} / \alpha \mathrm{S}^{\mathrm{U}}$ equilibrium is disturbed in PD and DLB patients. For each individual, 9 different brain regions were analyzed, reflecting the temporal development of LB pathology across the limbic and neocortical regions. Amygdala, cortex of the parahippocampal (PHG) and anterior cingulate cortex (ACC) are affected earlier in the disease course, followed by cortex of the insula, middle temporal (MTG), anterior middle frontal gyri (AMFG), and lastly with involvement of the cortex of inferior parietal lobule (IPL). Heschl's gyrus (Heschl) and cortex of the occipital lobe (OC) are typically spared from LB pathology in PD or involved late in the disease course. Each brain region has been analyzed in biological and technical duplicates and one non-cross-linked control sample. The linear trendlines (slopes) across all nine brain regions is depicted for each individual. a Comparison of $\alpha \mathrm{S}^{\mathrm{H}} / \alpha \mathrm{S}^{\mathrm{U}}$ changes across the nine brain regions comparing controls, PD (Braak 4,5 and 6), PD patients with dementia (Braak 4 and 6) and DLB patients (Braak 6) which were all demented. PD patients exhibit significantly increased slopes compared to controls $(p=0.006)$ and significantly higher slopes than DLB patients

stepwise increase via midbrain toward the cortices, leading to a slow progression and late involvement of the cortex
C DLB Braak 6 comparison of $\alpha S^{H} / \alpha S^{U}$ ratios across different brain regions

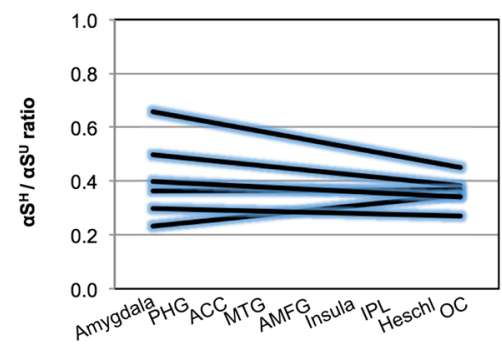

$f$ PD Braak 6 comparison of $\alpha S^{H} / \alpha S^{U}$ ratios across different brain regions

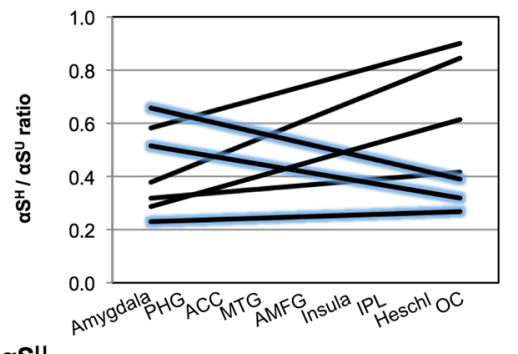

h Comparison of $\alpha^{H} / \alpha S^{U}$

ratios across different brain regions

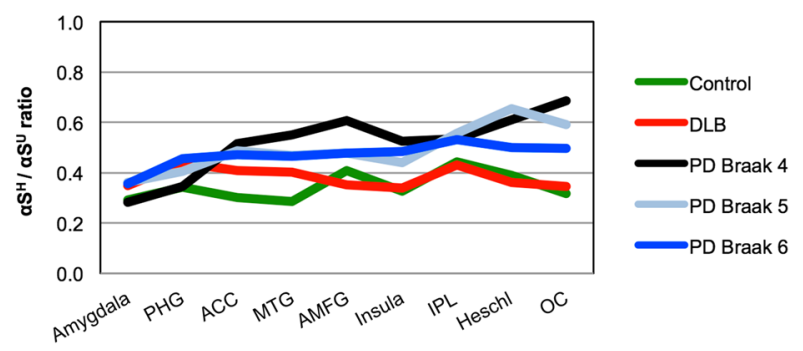

$(p=0.003)$. Mean with standard error of the mean (SEM). b Individual slopes of all controls across the nine brain regions $(n=10)$. $\mathbf{c}$ Individual slopes of all DLB patients across the nine brain regions $(n=6)$. DLB patients with dementia are displayed in blue enclosed lines. d Individual slopes of PD Braak 4 patients across the nine brain regions $(n=3)$. PD patients with dementia are displayed in blue enclosed lines. e Individual slopes of all PD Braak 5 patients across the nine brain regions $(n=3)$. f Individual slopes of PD Braak 6 patients across the nine brain regions $(n=7)$. PD patients with dementia are displayed in blue enclosed lines. $\mathrm{g}$ A semiquantitative LB score demonstrates increased amounts of LBs in later affected brain areas of PD and DLB Braak 6 patients. The mean of the score is displayed (controls $n=10$, DLB $n=6$, PD $n=13)$. h Comparison of mean $\alpha \mathrm{S}^{\mathrm{H}} / \alpha \mathrm{S}^{\mathrm{U}}$ changes across the nine brain regions comparing controls, $\mathrm{PD}$ and DLB patients (controls $n=10$, DLB $n=6$, PD $n=13$ ). DLB and PD Braak 6 patients exhibit lower slopes (decreased $\alpha \mathrm{S}^{\mathrm{H}} / \alpha \mathrm{S}^{\mathrm{U}}$ ratios) in the later affected brain regions

(PD pattern), or a fast neuropathological progression from brain stem areas to cortical brain regions in DLB patients. 


\section{a PD Braak 6}

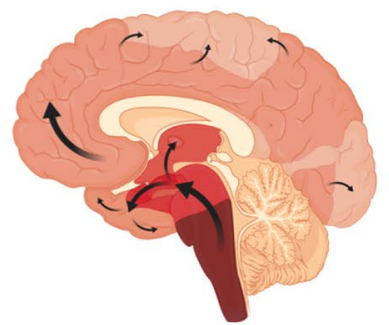

aggregated $\alpha \mathrm{S}$

\section{b DLB and PD Braak 6 with dementia}

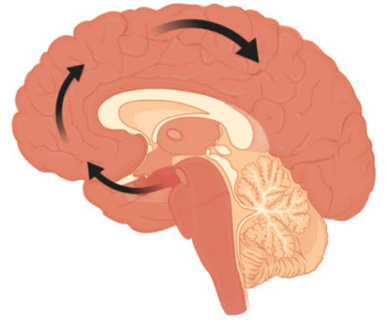

aggregated aS
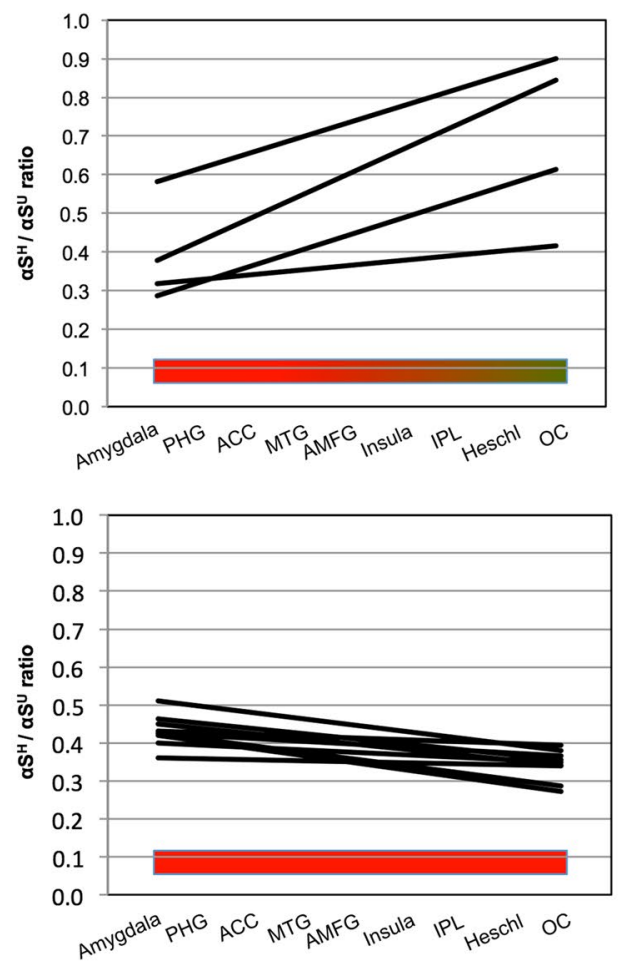

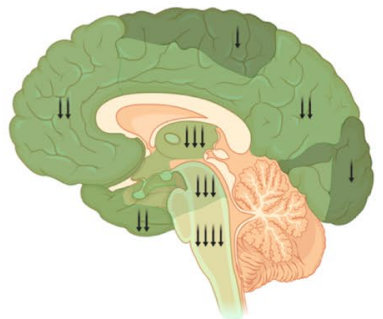

aggregation-resistant $\alpha \mathrm{S}^{\mathrm{H}}$

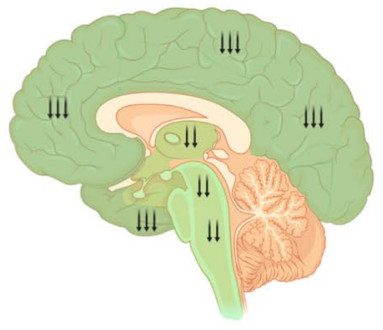

aggregation-resistant $\alpha \mathrm{S}^{\mathrm{H}}$
Fig. 5 Differences of the $\alpha \mathrm{S}^{\mathrm{H}} / \alpha \mathrm{S}^{\mathrm{U}}$ equilibriums comparing demented and cognitively intact PD and DLB patients Braak 6. The schematic on the left side depicts the propagation of aggregated $\alpha \mathrm{S}$ according to the classical Braak LB stages. For each individual, nine different brain regions were analyzed, reflecting the temporal development of

\section{Discussion}

Our study demonstrated that (i) $\alpha \mathrm{S}^{\mathrm{H}}$ multimers are present in human post-mortem brain tissue and exhibit a physiological, helical secondary structure, making them resistant to spontaneous as well as "prion-like" amyloid aggregation; (ii) the disequilibrium of $\alpha \mathrm{S}^{\mathrm{H}}$ and $\alpha \mathrm{S}^{\mathrm{U}}$ is brain region specific and associated with the spreading theory of $\alpha S$ and with clinical features such as dementia. In $\mathrm{PD}, \alpha \mathrm{S}^{\mathrm{H}} / \alpha \mathrm{S}^{\mathrm{U}}$ ratio reflects the regional aggregation transmission of LB pathology as proposed by Braak [8]. In contrast, demented DLB and PD Braak 6 patients exhibit especially low $\alpha \mathrm{S}^{\mathrm{H}} / \alpha \mathrm{S}^{\mathrm{U}}$ ratios in the neocortical regions. These results are in line with current and previous analysis in familial PD of in vitro and in vivo models on $\alpha \mathrm{S}^{\mathrm{H}}$, especially the helical $\alpha \mathrm{S}$ tetramer $[4,27,59$, 62]. The disequilibrium of all $\alpha \mathrm{S}^{\mathrm{H}}$ species in fPD models (putative $60 \mathrm{kDa}, 80 \mathrm{kDa}$ and $100 \mathrm{kDa}$ after SDS-PAGE) has previously been demonstrated [4, 14, 33, 46]. Our study extends the current knowledge on $\alpha \mathrm{S}^{\mathrm{H}}$, demonstrating the importance of the $\alpha \mathrm{S}^{\mathrm{H}} / \alpha \mathrm{S}^{\mathrm{U}}$ equilibrium in healthy human brain tissue and the region-specific disturbance in sporadic PD and DLB patients. Crucially, it provides a potential explanation for region-specific LB pathology in both PD and DLB. Along with these findings, our results indicate
LB pathology across the limbic and neocortical regions. Individual slopes of all patients (PD Braak $6 n=4$, PD and DLB with dementia $n=9)$ are shown in the middle schematic. The schematic on the right side shows the proposed decreased amount of $\alpha \mathrm{S}^{\mathrm{H}}$ in the different brain regions

that the absolute amount of $\alpha \mathrm{S}$ might not be detrimental per se; rather, the equilibrium of physiological aggregationresistant and aggregation-prone forms of the $\alpha \mathrm{S}$ protein, which might be influenced by intrinsic cellular, metabolic and genetic properties of different neuronal subpopulations $[1,57]$, is important. As already mentioned, we have to recognize that some controls also display lower than average $\alpha \mathrm{S}^{\mathrm{H}} / \alpha \mathrm{S}^{\mathrm{U}}$ across different brain regions; thus, individual and especially cortical perturbations of the complex $\alpha \mathrm{S}^{\mathrm{H}} / \alpha \mathrm{S}^{\mathrm{U}}$ equilibrium as well as between free and membrane-bound states may be responsible for the neuropathological and clinical features as well as the progressive neurotoxicity in PD and DLB patients as already discussed elsewhere [20]. These are important factors to consider in the development of effective therapeutic targeting and effective $\alpha \mathrm{S}$ biomarker assays. Furthermore, the equilibrium of $\alpha \mathrm{S}^{\mathrm{H}} / \alpha \mathrm{S}^{\mathrm{U}}$ could be therapeutically shifted by small molecules supporting aggregation resistance in disease-affected cells. Our earlier work [51] showed the role of lipids in stabilizing protective $\alpha \mathrm{S}^{\mathrm{H}}$, indicating that small molecule design mimicking this lipid-mediated stabilization, or targeting lipid metabolism directly, might be a viable therapeutic approach $[19,30]$.

Our in vitro data here and a recently published in vivo model [46] indicate a causal role for $\alpha \mathrm{S}^{\mathrm{H}}$ destabilization 
in neurodegeneration, but it remains unclear whether further shifts in the equilibrium of $\alpha \mathrm{S}^{\mathrm{H}}$ and $\alpha \mathrm{S}^{\mathrm{U}}$ are a part of ongoing progressive pathology in synucleinopathies, maybe further accelerated by the presence of tau or Abeta pathology in the case of DLB. $\alpha \mathrm{S}^{\mathrm{H}}$ destabilization could possibly result in different pathological $\alpha S^{\mathrm{F}}$ conformations in the human patient. In addition, these $\alpha \mathrm{S}$ conformations could differentially impact neuronal vulnerability by $\alpha \mathrm{S}^{\mathrm{H}}$ destabilization in a region-specific manner $[1,17,32]$, thereby concluding whether local neuronal vulnerability or "prionlike" aggregation transmission explains disease progression patterns [58]. The answer, implied here by our data, is that both mechanisms coexist, since "prion-like" aggregation and transmission get directed by local vulnerabilities. However, further studies have to answer the question how the equilibrium of $\alpha \mathrm{S}^{\mathrm{H}}$ and $\alpha \mathrm{S}^{\mathrm{U}}$ is disturbed during aging and progression of synucleinopathies. Our study mainly focused on limbic and neocortical regions in patients with DLB and PD with most advanced Braak stage 6 neocortical LB pathology. Non-classical PD patients, in which the LB pathology does not follow the classical Braak LB staging, might not show the same disequilibriums of $\alpha \mathrm{S}^{\mathrm{H}} / \alpha \mathrm{S}^{\mathrm{U}}$. We also did not present data on early affected brain regions, such as nucleus coeruleus, nucleus vagus or substantia nigra, given the low availability of these tissues. Still, we have demonstrated in our neuronal cell model that a general destabilization of $\alpha \mathrm{S}^{\mathrm{H}}$ is detrimental to aggregation resistance and that stabilizing agents such has SCDi could have a beneficial effect in sporadic PD regardless of the region specificity being applicable to every patient.

Overall, our current findings provide a novel mechanism, in which the equilibrium of physiological aggregation-resistant $\alpha \mathrm{S}^{\mathrm{H}}$ and physiological aggregation-prone $\alpha \mathrm{S}^{\mathrm{U}}$ is disturbed in sporadic PD and DLB patients. This brain region-specific pathology suggests pathways that explain progressive aggregation transmission of LB pathology in the human brain along different regions in DLB vs. PD. We propose that a stabilization of physiological aggregationresistant $\alpha S^{\mathrm{H}}$ in PD and DLB patients may be beneficial in slowing down the process of neurodegeneration, analogous to efforts currently underway toward stabilizing transthyretin in familial amyloid polyneuropathy $[11,41]$. Beyond therapeutic applications, the ratio of $\alpha \mathrm{S}^{\mathrm{H}} / \alpha \mathrm{S}^{\mathrm{U}}$ can be used as a biomarker of disease progression.

Supplementary Information The online version contains supplementary material available at https://doi.org/10.1007/s00401-022-02406-7.

Acknowledgements We thank our colleagues at the Ann Romney Center for Neurologic Diseases and the Dementia Research Institute @ UCL as well as the Department for Neurology in Bonn for many helpful discussions. We thank Dr. Mel Feany and her team at the Department of pathology at Harvard Medical School, Boston, for histopathological help.
Author contributions $\mathrm{LdB}$ and $\mathrm{ZJ}$ : sample curation; LdB, AHW, EM, ZJ, LZ, JS, HJ, MR, LL, MS, MF, TL, UD and TB: data curation; LdB and TB: formal analysis; LdB, AHW, EM, ZJ, LZ, JS, HJ, MR, LL, MS, MF, TL, UD and TB: investigation; LdB: writing-original draft; AHW, EM, ZJ, LZ, JS, HJ, MR, LL, MS, MF, TL, UD and TB: writing-review and editing; LdB, ZJ and TB: conceptualization; TB: supervision; $\mathrm{LdB}$ and $\mathrm{TB}$ : funding acquisition.

Funding This work was supported by grants from the UK Dementia Research Institute (DRI), which receives its funding from DRI Ltd., the UK Medical Research Council and Alzheimer's Society, and Alzheimer's Research UK (to TB); the US National Institute of Neurological Disorders and Stroke grants (U54-NS110435, R01-NS109209, and R21-NS107950 to TB); the Parkinson's Disease Foundation Stanley Fahn Award (PF-JFA-1884 to TB); the Eisai Pharmaceutical postdoctoral programme to TB; and the Chan Zuckerberg Collaborative Pairs Initiative (to TB) and the Thiemann Foundation (to LdB) and the Deutsche Forschungsgemeinschaft (DFG, German Research Foundation) - Projektnummer 386936527 (MS).

Data availability All data are available in the main text or the supplementary materials.

\section{Declarations}

Conflict of interest Zane Jaunmuktane is a member of Acta Neuropathologica's Editorial Board and was not involved in the assessment or decision-making process for this manuscript.

Open Access This article is licensed under a Creative Commons Attribution 4.0 International License, which permits use, sharing, adaptation, distribution and reproduction in any medium or format, as long as you give appropriate credit to the original author(s) and the source, provide a link to the Creative Commons licence, and indicate if changes were made. The images or other third party material in this article are included in the article's Creative Commons licence, unless indicated otherwise in a credit line to the material. If material is not included in the article's Creative Commons licence and your intended use is not permitted by statutory regulation or exceeds the permitted use, you will need to obtain permission directly from the copyright holder. To view a copy of this licence, visit http://creativecommons.org/licenses/by/4.0/.

\section{References}

1. Alegre-Abarrategui J, Brimblecombe KR, Roberts RF, VelentzaAlmpani E, Tilley BS, Bengoa-Vergniory N et al (2019) Selective vulnerability in $\alpha$-synucleinopathies. Acta Neuropathol 138:681704. https://doi.org/10.1007/s00401-019-02010-2

2. Angelova DM, Brown DR (2018) Model senescent microglia induce disease related changes in $\alpha$-synuclein expression and activity. Biomolecules. https://doi.org/10.3390/biom8030067

3. Bargar C, Wang W, Gunzler SA, LeFevre A, Wang Z, Lerner AJ et al (2021) Streamlined alpha-synuclein RT-QuIC assay for various biospecimens in Parkinson's disease and dementia with Lewy bodies. Acta Neuropathol Commun 9:62. https://doi.org/10.1186/ s40478-021-01175-w

4. Bartels T, Choi JG, Selkoe DJ (2011) alpha-Synuclein occurs physiologically as a helically folded tetramer that resists aggregation. Nature 477:107-110. https://doi.org/10.1038/nature10324

5. Baulac S, LaVoie MJ, Strahle J, Schlossmacher MG, Xia W (2004) Dimerization of Parkinson's disease-causing DJ-1 and 
formation of high molecular weight complexes in human brain. Mol Cell Neurosci 27:236-246. https://doi.org/10.1016/j.mcn. 2004.06.014

6. Bhumkar A, Magnan C, Lau D, Jun ESW, Dzamko N, Gambin Y et al (2021) Single-molecule counting coupled to rapid amplification enables detection of $\alpha$-synuclein aggregates in cerebrospinal fluid of Parkinson's disease patients. Angew Chem Int Ed Engl. https://doi.org/10.1002/anie.202014898

7. Bongianni M, Ladogana A, Capaldi S, Klotz S, Baiardi S, Cagnin A et al (2019) $\alpha$-Synuclein RT-QuIC assay in cerebrospinal fluid of patients with dementia with Lewy bodies. Ann Clin Transl Neurol 6:2120-2126. https://doi.org/10.1002/acn3.50897

8. Braak H, Del TK, Rüb U, de Vos RA, Jansen Steur EN, Braak E (2003) Staging of brain pathology related to sporadic Parkinson's disease. Neurobiol Aging 24:197-211. https://doi.org/10.1016/ S0197-4580(02)00065-9

9. Burré J, Vivona S, Diao J, Sharma M, Brunger AT, Südhof TC (2013) Properties of native brain $\alpha$-synuclein. Nature 498:1-6. https://doi.org/10.1038/nature12125

10. Candelise N, Schmitz M, Llorens F, Villar-Piqué A, Cramm M, Thom T et al (2019) Seeding variability of different alpha synuclein strains in synucleinopathies. Ann Neurol 85:691-703. https://doi.org/10.1002/ana.25446

11. Coelho LF, Martins da Silva A, Waddington Cruz M, PlanteBordeneuve V, Lozeron P, Suhr OB et al (2012) Tafamidis for transthyretin familial amyloid polyneuropathy: a randomized, controlled trial. Neurology 79:785-792. https://doi.org/10.1212/ WNL.0b013e3182661eb1

12. Dettmer U, Newman AJ, Luth ES, Bartels T, Selkoe D (2013) In vivo cross-linking reveals principally oligomeric forms of $\alpha$-synuclein and $\beta$-synuclein in neurons and non-neural cells. J Biol Chem 288:6371-6385. https://doi.org/10.1074/jbc.M112. 403311

13. Dettmer U, Newman AJ, von Saucken VE, Bartels T, Selkoe D, Von SVE et al (2015) KTKEGV repeat motifs are key mediators of normal $\alpha$-synuclein tetramerization: Their mutation causes excess monomers and neurotoxicity. Proc Natl Acad Sci USA 112:9596-9601. https://doi.org/10.1073/pnas.1505953112

14. Dettmer U, Newman AJ, Soldner F, Luth ES, Kim NC, Von SVE et al (2015) Parkinson-causing a-synuclein missense mutations shift native tetramers to monomers as amechanism for disease initiation. Nat Commun 6:1-15. https://doi.org/10.1038/ncomm s8314

15. Dettmer U, Ramalingam N, von Saucken VE, Kim T-E, Newman AJ, Terry-Kantor E et al (2017) Loss of native alpha-synuclein multimerization by strategically mutating its amphipathic helix causes abnormal vesicle interactions in neuronal cells. Hum Mol Genet 26:3466-3481. https://doi.org/10.1093/hmg/ddx227

16. Donadio V, Wang Z, Incensi A, Rizzo G, Fileccia E, Vacchiano V et al (2021) In vivo diagnosis of synucleinopathies: a comparative study of skin biopsy and RT-QuIC. Neurology. https://doi.org/10. 1212/WNL.0000000000011935

17. Engelender S, Isacson O (2017) The threshold theory for Parkinson's disease. Trends Neurosci 40:4-14. https://doi.org/10.1016/j. tins.2016.10.008

18. Fairfoul G, McGuire LI, Pal S, Ironside JW, Neumann J, Christie S et al (2016) Alpha-synuclein RT-QuIC in the CSF of patients with alpha-synucleinopathies. Ann Clin Transl Neurol 3:812-818. https://doi.org/10.1002/acn3.338

19. Fanning S, Haque A, Imberdis T, Baru V, Barrasa MI, Nuber S et al (2018) Lipidomic analysis of $\alpha$-synuclein neurotoxicity identifies stearoyl CoA desaturase as a target for parkinson treatment. Mol Cell. https://doi.org/10.1016/j.molcel.2018.11.028

20. Fanning S, Selkoe D, Dettmer U (2020) Parkinson's disease: proteinopathy or lipidopathy. NPJ Parkinsons Dis 6:1-9. https://doi. org/10.1038/s41531-019-0103-7
21. Fernandez RD, Lucas HR (2018) Mass spectrometry data confirming tetrameric alpha-synuclein N-terminal acetylation. Data $\mathrm{Br}$ 20:1686-1691. https://doi.org/10.1016/j.dib.2018.09.026

22. Fernández RD, Lucas HR (2018) Isolation of recombinant tetrameric N-acetylated $\alpha$-synuclein. Protein Expr Purif 152:146-154. https://doi.org/10.1016/j.pep.2018.07.008

23. Fernández RD, Lucas HR (2018) Mass spectrometry data confirming tetrameric $\alpha$-synuclein $\mathrm{N}$-terminal acetylation. Data $\mathrm{Br}$ 20:1686-1691. https://doi.org/10.1016/j.dib.2018.09.026

24. Garrido A, Fairfoul G, Tolosa ES, Martí MJ, Green A (2019) $\alpha$-synuclein RT-QuIC in cerebrospinal fluid of LRRK2-linked Parkinson's disease. Ann Clin Transl Neurol 6:1024-1032. https:// doi.org/10.1002/acn3.772

25. Groveman BR, Orrù CD, Hughson AG, Raymond LD, Zanusso G, Ghetti B et al (2018) Rapid and ultra-sensitive quantitation of disease-associated $\alpha$-synuclein seeds in brain and cerebrospinal fluid by $\alpha$ Syn RT-QuIC. Acta Neuropathol Commun 6:7. https:// doi.org/10.1186/s40478-018-0508-2

26. Gurry T, Ullman O, Fisher CK, Perovic I, Pochapsky T, Stultz CM (2013) The dynamic structure of $\alpha$-synuclein multimers. J Am Chem Soc 135:3865-3872. https://doi.org/10.1021/ja310518p

27. Gurry T, Ullman O, Fisher CK, Perovic I, Pochapsky T, Stultz CM (2013) The dynamic structure of alpha-synuclein multimers. J Am Chem Soc 135:3865-3872. https://doi.org/10.1021/ja310518p

28. Han J-Y, Jang H-S, Green AJE, Choi YP (2020) RT-QuIC-based detection of alpha-synuclein seeding activity in brains of dementia with Lewy Body patients and of a transgenic mouse model of synucleinopathy. Prion 14:88-94. https://doi.org/10.1080/19336 896.2020.1724608

29. Imberdis T, Fanning S, Newman A, Ramalingam N, Dettmer U (2019) Studying $\alpha$-synuclein conformation by intact-cell crosslinking. In: Bartels T (ed) Alpha-Synuclein methods protoc. Springer, New York, pp 77-91

30. Imberdis T, Negri J, Ramalingam N, Terry-Kantor E, Ho GPH, Fanning $S$ et al (2019) Cell models of lipid-rich $\alpha$-synuclein aggregation validate known modifiers of $\alpha$-synuclein biology and identify stearoyl-CoA desaturase. Proc Natl Acad Sci USA 116:20760-20769. https://doi.org/10.1073/pnas.1903216116

31. Iranzo A, Fairfoul G, Ayudhaya ACN, Serradell M, Gelpi E, Vilaseca I et al (2021) Detection of $\alpha$-synuclein in CSF by RTQuIC in patients with isolated rapid-eye-movement sleep behaviour disorder: a longitudinal observational study. Lancet Neurol 20:203-212. https://doi.org/10.1016/S1474-4422(20)30449-X

32. Jaunmuktane Z, Brandner S (2019) On the journey to uncover the causes of selective cellular and regional vulnerability in neurodegeneration. Acta Neuropathol 138:677-680. https://doi.org/10. 1007/s00401-019-02079-9

33. Kim S, Yun SP, Lee S, Umanah GE, Bandaru VVR, Yin X et al (2018) GBA1 deficiency negatively affects physiological alphasynuclein tetramers and related multimers. Proc Natl Acad Sci USA 115:798-803. https://doi.org/10.1073/pnas.1700465115

34. Kordower JH, Brundin P (2009) Lewy body pathology in longterm fetal nigral transplants: is Parkinson's disease transmitted from one neural system to another? Neuropsychopharmacology 34:254. https://doi.org/10.1038/npp.2008.161

35. Kordower JH, Chu Y, Hauser RA, Freeman TB, Olanow CW (2008) Lewy body-like pathology in long-term embryonic nigral transplants in Parkinson's disease. Nat Med 14:504-506. https:// doi.org/10.1038/nm1747

36. Lashuel HA, Overk CR, Oueslati A, Masliah E (2013) The many faces of $\alpha$ - synuclein: from structure and toxicity to therapeutic target. Nat Rev Neurosci 14:38-48. https://doi.org/10.1038/nrn34 06

37. De Luca CMG, Elia AE, Portaleone SM, Cazzaniga FA, Rossi M, Bistaffa E et al (2019) Efficient RT-QuIC seeding activity for $\alpha$-synuclein in olfactory mucosa samples of patients with 
Parkinson's disease and multiple system atrophy. Transl Neurodegener 8:24. https://doi.org/10.1186/s40035-019-0164-x

38. Luth ES, Bartels T, Dettmer U, Kim NC, Selkoe DJ (2015) Purification of $\alpha$-synuclein from human brain reveals an instability of endogenous multimers as the protein approaches purity. Biochemistry 54:279-292. https://doi.org/10.1021/bi501188a

39. Manne S, Kondru N, Hepker M, Jin H, Anantharam V, Lewis M et al (2019) Ultrasensitive detection of aggregated $\alpha$-synuclein in glial cells, human cerebrospinal fluid, and brain tissue using the RT-QuIC assay: new high-throughput neuroimmune biomarker assay for parkinsonian disorders. J Neuroimmune Pharmacol 14:423-435. https://doi.org/10.1007/s11481-019-09835-4

40. Manne S, Kondru N, Jin H, Serrano GE, Anantharam V, Kanthasamy A et al (2020) Blinded RT-QuIC analysis of $\alpha$-synuclein biomarker in skin tissue from Parkinson's disease patients. Mov Disord 35:2230-2239. https://doi.org/10.1002/mds.28242

41. Maurer MS, Schwartz JH, Gundapaneni B, Elliott PM, Merlini G, Waddington-Cruz $\mathrm{M}$ et al (2018) Tafamidis treatment for patients with transthyretin amyloid cardiomyopathy. N Engl J Med 379:1007-1016. https://doi.org/10.1056/NEJMoa1805689

42. McKeith IG, Dickson DW, Lowe J, Emre M, O’Brien JT, Feldman $\mathrm{H}$ et al (2005) Diagnosis and management of dementia with Lewy bodies: third report of the DLB Consortium. Neurology 65:18631872. https://doi.org/10.1212/01.wnl.0000187889.17253.b1

43. Meade RM, Fairlie DP, Mason JM (2019) Alpha-synuclein structure and Parkinson's disease - lessons and emerging principles. Mol Neurodegener 14:1-14. https://doi.org/10.1186/ s13024-019-0329-1

44. Neupane K, Solanki A, Sosova I, Belov M, Woodside MT (2014) Diverse metastable structures formed by small oligomers of $\alpha$-synuclein probed by force spectroscopy. PLoS One 9:e86495. https://doi.org/10.1371/journal.pone.0086495

45. Nuber S, Nam AY, Rajsombath MM, Cirka H, Hronowski X, Wang J et al (2021) A stearoyl-coenzyme A desaturase inhibitor prevents multiple Parkinson disease phenotypes in $\alpha$-synuclein mice. Ann Neurol 89:74-90. https://doi.org/10.1002/ana.25920

46. Nuber S, Rajsombath M, Minakaki G, Winkler J, Müller CP, Ericsson $\mathrm{M}$ et al (2018) Abrogating native $\alpha$-synuclein tetramers in mice causes a L-DOPA-responsive motor syndrome closely resembling Parkinson's disease. Neuron 100:75-90.e5. https://doi. org/10.1016/j.neuron.2018.09.014

47. Park S-J, Lee Y-J, Park J-H, Jin H-T, Choi M-J, Jung C-G et al (2021) Establishment of method for the determination of aggregated $\alpha$-synuclein in DLB patient using RT-QuIC assay. Protein Pept Lett 28:115-120. https://doi.org/10.2174/092986652766620 0420105352

48. Pavlou MAS, Colombo N, Fuertes-Alvarez S, Nicklas S, Cano LG, Marin MC et al (2019) Diagnosis and management of dementia with Lewy bodies: third report of the DLB Consortium [1]. Acta Neuropathol 9:1-25. https://doi.org/10.1212/01.wnl.0000224698. 67660.45

49. Rajsombath MM, Nam AY, Ericsson M, Nuber S (2019) Female sex and brain-selective estrogen benefit $\alpha$-synuclein tetramerization and the PD-like motor syndrome in $3 \mathrm{~K}$ transgenic mice. J Neurosci 39:7628-7640. https://doi.org/10.1523/JNEUROSCI. 0313-19.2019

50. Rossi M, Candelise N, Baiardi S, Capellari S, Giannini G, Orrù CD et al (2020) Ultrasensitive RT-QuIC assay with high sensitivity and specificity for Lewy body-associated synucleinopathies. Acta Neuropathol 140:49-62. https://doi.org/10.1007/ s00401-020-02160-8

51. Rovere M, Sanderson JB, Fonseca-Ornelas L, Patel DS, Bartels T (2018) Refolding of helical soluble alpha-synuclein through transient interaction with lipid interfaces. FEBS Lett 592:1464-1472. https://doi.org/10.1002/1873-3468.13047

52. van Rumund A, Green AJE, Fairfoul G, Esselink RAJ, Bloem BR, Verbeek MM (2019) $\alpha$-Synuclein real-time quaking-induced conversion in the cerebrospinal fluid of uncertain cases of parkinsonism. Ann Neurol 85:777-781. https://doi.org/10.1002/ana.25447

53. Saijo E, Groveman BR, Kraus A, Metrick M, Orrù CD, Hughson AG et al (2019) Ultrasensitive RT-QuIC seed amplification assays for disease-associated tau, $\alpha$-synuclein, and prion aggregates. Methods Mol Biol 1873:19-37. https://doi.org/10.1007/ 978-1-4939-8820-4_2

54. Sanderson JB, De S, Jiang H, Rovere M, Jin M, Zaccagnini L et al (2020) Analysis of $\alpha$-synuclein species enriched from cerebral cortex of humans with sporadic dementia with Lewy bodies. Brain Commun 2:010. https://doi.org/10.1093/braincomms/fcaa010

55. Sano K, Atarashi R, Satoh K, Ishibashi D, Nakagaki T, Iwasaki Y et al (2018) Prion-like seeding of misfolded $\alpha$-synuclein in the brains of dementia with Lewy body patients in RTQUIC. Mol Neurobiol 55:3916-3930. https://doi.org/10.1007/ s12035-017-0624-1

56. Sherer TB, Betarbet R, Greenamyre JT (2001) Pathogenesis of Parkinson's disease. Curr Opin Investig Drugs 2:657-662

57. Tong J, Wong H, Guttman M, Ang LC, Forno LS, Shimadzu M et al (2010) Brain $\alpha$-synuclein accumulation in multiple system atrophy, Parkinson's disease and progressive supranuclear palsy: a comparative investigation. Brain 133:172-188. https://doi.org/ 10.1093/brain/awp282

58. Walsh DM, Selkoe DJ (2016) A critical appraisal of the pathogenic protein spread hypothesis of neurodegeneration. Nat Rev Neurosci 17:251-260. https://doi.org/10.1038/nrn.2016.13

59. Wang W, Perovic I, Chittuluru J, Kaganovich A, Nguyen LTT, Liao J et al (2011) A soluble alpha-synuclein construct forms a dynamic tetramer. Proc Natl Acad Sci 108:17797-17802. https:// doi.org/10.1073/pnas.1113260108

60. Wang Z, Becker K, Donadio V, Siedlak S, Yuan J, Rezaee M et al (2020) Skin $\alpha$-synuclein aggregation seeding activity as a novel biomarker for Parkinson disease. JAMA Neurol 78:1-11. https:// doi.org/10.1001/jamaneurol.2020.3311

61. Xu L, Bhattacharya S, Thompson D (2018) Re-designing the $\alpha$-synuclein tetramer. Chem Commun 54:8080-8083. https://doi. org/10.1039/c8cc04054k

62. Xu L, Bhattacharya S, Thompson D (2019) On the ubiquity of helical alpha-synuclein tetramers. Phys Chem Chem Phys 21:12036-12043. https://doi.org/10.1039/c9cp02464f

Publisher's Note Springer Nature remains neutral with regard to jurisdictional claims in published maps and institutional affiliations. 